\title{
Organic Agriculture 3.0 is innovation with research
}

\author{
Gerold Rahmann (D) - M. Reza Ardakani • Paolo Bàrberi • Herwart Boehm • Stefano Canali • \\ Mahesh Chander • Wahyudi David • Lucas Dengel • Jan Willem Erisman • \\ Ana C. Galvis-Martinez • Ulrich Hamm • Johannes Kahl • Ulrich Köpke • Stefan Kühne •
}

S. B. Lee • Anne-Kristin Løes • Jann Hendrik Moos • Daniel Neuhof •

Jakko Tapani Nuutila • Victor Olowe $\cdot$ Rainer Oppermann • Ewa Rembiałkowska •

Jim Riddle • Ilse A. Rasmussen • Jessica Shade • Sang Mok Sohn • Mekuria Tadesse •

Sonam Tashi • Alan Thatcher • Nazim Uddin • Peter von Fragstein und Niemsdorff •

Atle Wibe • Maria Wivstad • Wu Wenliang • Raffaele Zanoli

Received: 19 May 2016 / Accepted: 17 November 2016/Published online: 3 December 2016

(C) Springer Science+Business Media Dordrecht 2016

\begin{abstract}
Organic agriculture can and should play an important role in solving future challenges in producing food. The low level of external inputs combined with
\end{abstract}

\section{G. Rahmann $(\bowtie)$}

International Society of Organic Farming Research, c/o

Thünen-Institute of Organic Farming, German Federal Research

Centre for Rural Areas, Forestry and Fishery, Trenthorst 32,

23847 Westerau, Germany

e-mail: gerold.rahmann@gmx.de

M. Reza Ardakani

Department of Agronomy and Plant Breeding, Faculty of Agriculture and Natural Resources, Islamic Azad University, Karaj, Iran

P. Bàrberi

Institute of Life Sciences, Scuola Superiore Sant'Anna, Piazza Martini della Liberta 33, 56127 Pisa, Italy

\section{H. Boehm · J. H. Moos • R. Oppermann}

Thünen-Institute of Organic Farming, German Federal Research Centre for Rural Areas, Forestry and Fishery, Trenthorst 32,

23847 Westerau, Germany

\section{S. Canali}

Consiglio per la ricerca in agricoltura l'analisi dell'economia agraria (CREA), Centro per lo studio delle relazioni tra pianta e suolo (RPS), Via della Navicella 2, 00184 Rome, Italy

M. Chander

Division of Extension Education, Indian Veterinary Research Institute, Izatnagar, UP 243122, India knowledge on sustainablity minimizes environmental contamination and can help to produce more food for more people without negatively impacting our

\section{W. David}

Program Studi Ilmu Dan Teknologi Pangan, Universitas Bakrie, Gelanggang Mahasiswa Soemantri Brodjonegoro, Suite GF-22, Jl.H.R.Rasuna Said Kav. C-22 Kuningan, Jakarta 12920, Indonesia

L. Dengel

EcoPro, Aurosarjan Complex, Auroshilpam, IND-605101, Auroville, Tamil Nadu 605101, India

\section{J. W. Erisman}

Louis Bolk Institute, Hoofdstraat 24, 3972 LA Driebergen, and VU Amsterdam, De Boelelaan 1091, 1081 HV Amsterdam, The Netherlands

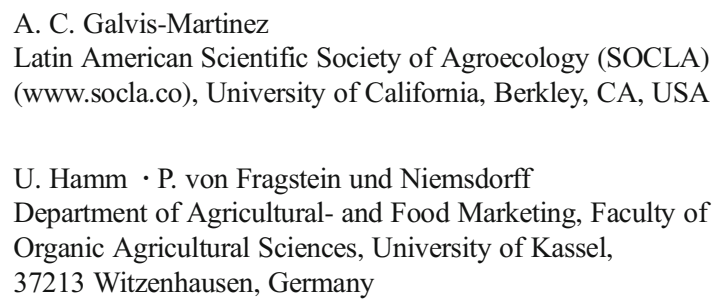

U. Hamm · P. von Fragstein und Niemsdorff Department of Agricultural- and Food Marketing, Faculty of Organic Agricultural Sciences, University of Kassel, 37213 Witzenhausen, Germany

J. Kahl

Department of Nutrition, Exercise and Sports, Preventive and Clinical Nutrition, University of Copenhagen, 2200 København N, Denmark 
environment. Organic agriculture not only includes farming as a production practice but it also includes processing, trade and consumption. Nevertheless, Organic agriculture must always evolve to overcome emerging challenges. Science-based knowledge attained through dedicated research is required to strengthen organic food and farming as a means to solve future challenges. In 2010, a global discussion about Organic 3.0 was initiated to address current problems our agri-food systems are facing. Many scientifically and practically proven results are already available to make organic agriculture a strong tool to solve some of these challenges. However, the organic agri-food system has to be developed further to fulfill its potential. The contribution of organic agriculture to help solve current problems linked to food security and environmental quality was discussed during the

\section{U. Köpke · D. Neuhof}

Institute of Organic Agriculture, University of Bonn,

Katzenburgweg 3, 53115 Bonn, Germany

\section{S. Kühne}

Institute for Strategies and Technology Assessment, Julius Kühn-Institute, Stahnsdorfer Damm 81, 14532 Kleinmachnow, Germany

\section{S. B. Lee}

Organic Agriculture Division, Department of Agricultural Environment, National Academy of Agricultural Science, Rural Development Administration (RDA), Nongsaengmyeongro 166, Wanju-gun, Jeonbuk 565-851, Republic of Korea

A.-K. Løes · A. Wibe

Norwegian Centre for Organic Agriculture (NORSØK), Gunnars veg 6, 6630 Tingvoll, Norway

\section{J. T. Nuutila}

Finnish Organic Research Institute. Natural Resources Institute Finland, University of Helsinki, Lönnrotinkatu 7, 50100 Mikkeli, Finland

\section{Olowe}

Institute of Food Security, Environmental Resources and Agricultural Research (IFSERAR), Federal University of Agriculture, Abeokuta P.M.B., Abeokuta 2240, Nigeria

\section{E. Rembiałkowska}

Department of Functional and Organic Food and Commodities, Faculty of Human Nutrition and Consumer Studies, Warsaw University of Life Sciences, Nowoursynowska 159 c,

02-787 Warszawa, Poland

\section{J. Riddle}

The Ceres Trust, 150 South Wacker Drive, Suite 2400, Chicago, IL 60606, USA
International Society of Organic Agricultural Research (ISOFAR) Symposium "Organic 3.0 is Innovation with Research”, held September 20-22, 2015, in conjunction with the first ISOFAR International Organic Expo, in Goesan County, Republic of Korea. Some of the world's most active scientists in organic agriculture attended the symposium. This paper is a result of their discussions and aims to give an overview of research conducted and required to strengthen organic agriculture in its ambitions to overcome agronomic challenges, contribute to food security and protect our common environment.

Keywords Organic 3.0 • Agri-ecology · ISOFAR · Ecological intensification - Organic agriculture - Organic food systems · Organic farming research · Global food challenges

\section{A. Rasmussen \\ ICROFS Foulum, P.O. Box 50, -8830 Tjele, DK, Denmark}

\section{J. Shade}

The Organic Center, Hall of the States, 444 N. Capitol St. NW, Suite 445A, Washington, D.C 20001, USA

\section{S. M. Sohn}

Research Institute of Organic Agriculture, Dankook University, Cheonan 330-714, Republic of Korea

M. Tadesse

Ethiopian Institute of Agricultural Research based at Addis Ababa, P.O. Box 2003, Addis Ababa, Ethiopia

\section{S. Tashi}

Royal University of Bhutan, Lobesa, Bhutan
A. Thatcher
Institute of Veterinary, Animal and Biomedical Sciences, Massey University, Palmerston North 4474, New Zealand
N. Uddin
Bangladesh Agricultural Research Institute BARI, Joydebpur, Bangladesh
M. Wivstad
Centre for Organic Food and Farming (EPOK), Swedish
University of Agricultural Sciences, Box 7043, 75007 Uppsala, Sweden
W. Wenliang Beijing, PC 1000193, China

\section{R. Zanoli}
Università Politecnica delle Marche, Via Brecce Bianche, 60129 Ancona, Italy
College of Natural Resources and Environmental Sciences, China Agricultural University, Yuanmingyuan Xilu Haidian District, 


\section{Introduction}

The future challenges in food production and consumption appear clear: (a) producing sufficient healthful, safe and affordable food for 9-11 billion people, (b) reducing pollution and greenhouse gas emissions derived from food production, processing, trading and consumption, (c) developing food chains driven by renewable energy and recycled nutrients, (d) adapting to climate change and mitigating greenhouse gas emissions, (e) protecting soils, water, air, biodiversity and landscapes and (f) taking into account current and emerging ethics, food habits, lifestyles and consumer needs.

Several findings from scientific research and practical application suggest that organic agriculture can help in tackling these future challenges (Arbenz et al. 2015). The "low external input" approach, risk minimizing strategies and ethically accepted production practices can help to produce more affordable food for an increased number of people while minimizing environmental impacts. However, resource efficiency, low-meat diets and reducing food waste are also essential factors that have to be be considered.

From a global perspective, organic agriculture is still a niche sector, as less than $1 \%$ of global farmland is managed organically and only a small proportion of the global population is consuming organic food in significant amounts. Production yields are relatively low, and the goals of organic agriculture, described in the principles and standards, are not achieved on every farm. This needs further development based on scientific evidence and good management practices.

Discussion about the future global development needs of organic agriculture was initiated by a number of farmers in 2010 (Braun et al. 2010; Strootdress et al. 2011) and was named Organic 3.0. The Bioland Association, the largest organic farmers' association in Germany (Rahmann et al. 2013), continued this discussion finally introducing the term Organic 3.0 at BioFach 2014 to the global discussion (Rützler and Reiter 2014). Several organic groups subsequently developed ideas towards Organic 3.0 and formulated strategies. BioAustria (Austria), Bio Suisse (Switzerland) and Bioland (Germany) have published a common Organic 3.0 paper (Niggli et al. 2015) in order to define goals for further development.

The suggested strategies for Organic 3.0 include empowerment of rural areas, ecofunctional intensification and development of food for health and well-being and are therefore in accordance with the Sustainable Development Goals (SDGs) passed by the UN General Assembly in September 2015 as "Post-2015 Agenda" (UN 2015a, b). Two of the 17 SDGs are of special relevance for Organic 3.0 strategies: SDG 2: "End hunger, achieve food security and improved nutrition and promote sustainable agriculture" and SDG 12: "Ensure sustainable consumption and production patterns".

The German Alliance for Agricultural Research (Hamm et al. 2016), the International Federation of Organic Agriculture Movements (IFOAM) EU group (Barabanova et al. 2015), the Technology Innovation Platform TIPI of IFOAM-Organic International (Niggli et al. 2014), the Italian Organic Research Strategy (Canali 2016) and the EU Technology Platform Organics (TPorganics 2016) have proposed how research should be directed and supported to achieve the aims of Organic 3.0. The International Society of Organic Agricultural Research (ISOFAR) discussed these strategies and the role of research during the ISOFAR Symposium "Organic 3.0 is Innovation with Research", held in September 20-22, 2015, in conjunction with the first ISOFAR International Organic Expo in Goesan County, Republic of Korea. The aim of this paper is to compile the outcomes of these discussions and give an overview of the scientific support for the claim that organic agriculture has a significant role to play to overcome the mentioned crucial challenges.

For this purpose, the authors will highlight the most relevant global challenges, show results from organic agriculture research that can be used to cope with these challenges and give an outline about which research will be needed to foster the development of Organic 3.0. A background section describing in brief the scientific base of Organic 1.0 and 2.0 development phases is provided ("Organic agriculture: science based from the start") before we discuss global challenges in "The base for Organic 3.0 research: future challenges of food and farming" and "Contribution of organic agriculture in addressing future challenges".

\section{Organic agriculture: science based from the start}

The Codex Alimentarius Commission of the FAO/ WHO (1999) has defined organic agriculture as follows: "Organic Agriculture is a holistic production management system which promotes and enhances agriecosystem health, including biodiversity, biological 
cycles and soil biological activity. It emphasizes the use of management practices in preference to the use of offfarm inputs, taking into account that regional conditions require locally adapted systems. This is accomplished by using, where possible, agronomic, biological, and mechanical methods, as opposed to using synthetic materials, to fulfill any specific function within the system".

\section{Organic 1.0}

The system of organic agriculture arose in the early twentieth century and has since gone through several stages, including Organic 1.0 and Organic 2.0, with Organic 3.0 currently under development (Niggli and Rahmann 2013). Organic 1.0 is defined as the period of organic pioneers, developing the vision of organic agriculture (OA). Organic 2.0 is the period of growth and marketing of organic, which has taken place in recent history. Finally, Organic 3.0 addresses future challenges and aims at entering organic agriculture on the global stage. These definitions were adopted by the global organic movement (Rahmann et al. 2013; Arbenz et al. 2015; Rützler and Reiter 2014; Niggli et al. 2015), and the stakeholders tried to define goals for further development from the perspectives of the associations and institutions involved.

Organic 1.0 was marked by several important discoveries and events around the turn of the twentieth century. For example, one of the first scientific fields influencing organic agricultural practices was "agricultural bacteriology" developed in the early 1900s. Scientists discovered nitrogen-fixing bacteria (Hellriegel and Wilfarth 1888; Beijerinck 1901), leading to increased knowledge about biological aspects of soil fertility and the importance of soil fauna and soil organic matter. Agricultural measures thought to be beneficial for soil fertility included the use of farmyard manure, fermentation or composting of farmyard manure, reduced or non-inversion tillage and the use of green manure.

Around the same time period, Rudolf Steiner's (1861-1925) series of lectures gave birth to the movement of biodynamic agriculture (Paull 2011). Steiner did not present a ready-to-use science-based organic agricultural system but rather concepts and practices of farming such as closed cycles, farms as organisms and holistic and spiritual thinking. Shortly after his death, farmers and scientists (e.g. E. Pfeiffer, L. Kolisko) started to apply, verify and improve his approaches on their farms to develop a more robust system of biodynamic farming (Paull 2011). Research institutes for biodynamic farming were established, e.g. in Järna, Sweden and Darmstadt, Germany.

Another development of Organic 1.0 happened under the leadership of Hans (1891-1988) and Maria (18941969) Müller, who developed the organic-biological system in Switzerland based on practical experiences. In addition to the systems developed from practice, work was being done on a theoretical background for the organic-biologic system by the microbiologist Hans Peter Rusch (1906-1977). Rusch was skeptical about the use of mineral fertilizers, and his main topics of interest were soil fertility, soil health and the formation of humus (Paulsen et al. 2009a, b).

In the English-speaking world, Lady Eve Balfour (1898-1990) and Sir Albert Howard (1873-1947) in the UK and Jerome Rodale (1898-1971) in the USA were the pioneer stakeholders of organic agriculture. Lady Balfour is known for her Haughley Experiment, one of the first long-term studies comparing organic with high external input of conventonal farming. Howard worked on composting urban wastes, plant breeding, plant health and soil fertility in India and was inspired by the sustainable farming practices he observed in Asian countries. Rodale, an editor, author and playwright, was an advocate for organic, popularizing the term to indicate food that was grown without pesticides. These individuals greatly influenced the organic agriculture movement in Great Britain and North America through their farming, advocacy and scientific work (Vogt 2000).

In Italy, Alfonso Draghetti (1888-1960), who worked at a public agricultural research station in Modena, published "Principi di Fisiologia dell'Azienda Agraria" (Physiological Principles of the Farm) in 1948, in which he discussed how biological principles support the theory that the farm functions as a whole (Draghetti 1948). Along with Francesco Garofalo, who founded the Associazione Suolo e Salute in Turin in 1969, and Ivo Totti (1914-1992), Draghetti is acknowledged as one of the fathers of organic farming research in Italy.

Organic 2.0

Beyond these early pioneers of organic, well based in research, many scientists have continued to encourage farmers to use organic methods through the 
establishment of the Organic 2.0 movement and founding of organic research institutes, associations and supporting groups. The International Federation of Organic Agriculture Movements (www.ifoam.bio) was founded in 1972 and located in Bonn, Germany. The four basic IFOAM principles (principle of fairness, principle of care, principle of health and principle of ecology, IFOAM 2005) are understood as "inter-connected" and formulated to "inspire action". These principles offer guidance for research in organic agriculture.

Because of the support and efforts of individual scientists and groups such as IFOAM, research facilities and institutions that conduct research on organic agriculture have been established worldwide (Vogt 2007). To date, most of these facilities and groups are located in western countries, but more recently, there has been increased organic establishment in developing countries.

The first organic agriculture research institutions were founded privately by individuals. One such institution was the Rodale Institute (www.rodaleinstitute. org), established in 1947 in Pennsylvania, USA. Others include the biodynamic research institute "Forschungsring", which was started in 1950 in Darmstadt, Germany (www.forschungsring.de); the Forschungsinstitut für biologischen Landbau (www. fibl.org) which was established in 1974 in Oberwil, Switzerland, and currently has headquarters in Frick, Switzerland, with branches in Frankfurt, Germany and Vienna, Austria; the Louis Bolk Institute in Driebergen, the Netherlands, which was founded in 1976 (www. louisbolk.org); the Elm Farm Research Centre (www. organicresearchcentre.com) in Newbury, Great Britain, which was established in 1982 and the Norwegian Centre for Organic Agriculture in Tingvoll, Norway, which was established in 1986.

Funding for organic research

Besides private funding in the last three decades, public funds for organic agricultural research have become increasingly available especially in Europe. However, there remains a gap between funds for organic and nonorganic agricultural research. Rahmann and Aksoy (2014) showed that in 2012, Germany spent about 87 million euros of public money for organic agricultural research (1.07 euros per capita). While this seems like a low funding level, other EU and EFTA members only spent 0.30 euro per capita on organic research, and the rest of the world spent 0.0005 euro per capita. In comparison, in Germany, 4 billion (50 euros per capita) and globally US $\$ 40$ billion (US $\$ 6$ per capita) were spent on conventional agriculture research. Thus, even in the country with the highest organic farming research funding rates, only $2 \%$ of the agricultural research funds were dedicated to organic, and the global average for organic research funding was only $0.04 \%$. In comparison to the organic market share, this is not an equitable distribution. In Germany, organic food in 2015 had a share of $3.8 \%$ of all food purchases, $6.7 \%$ of all farmland and $8 \%$ of all farms. On the global level, organic food had a share of $1 \%$ for purchases and farmland.

Federally funded organic projects

In the 1990s, the first EU-funded projects were carried out and a growing number of national research institutions became involved in EU calls. In the following years, organic agricultural research in the EU was funded by national or pan-European schemes. The fifth, sixth, seventh and Horizon 2020 framework programs of the EU all supported large projects that supported further development of organic agriculture. Famous examples include the organic plant breeding program, SOLIBAM; the market information program, EISfOM and the review of the European Action Plan for Organic Agriculture, ORGAP. All these efforts have been recorded in the open archive Organic E-prints (Organic E-prints 2016 http://orgprints.org).

In 2004, the CORE Organic program was initiated as a European Research Area Network supported by the EU. By 2016, this cooperation of European funding bodies financed 33 projects (CORE Organic, www. coreorganic.org). Also, national public funding programs on organic food systems have continued in some European countries since the late 1990s, such as Italy, Sweden and Denmark and Germany.

In the USA, federal funds have been available for organic research since 2002, with approximately US\$24 million specifically earmarked for organic research in the 2015 US Farm Bill. This is a significant increase from 1997, when the Organic Farming Research Foundation (OFRF) published the report "Searching for the O-Word". In this report, OFRF searched through more than 30,000 agricultural research projects in the US Department of Agriculture's research portfolio. The report showed that only 34 projects qualified as "strong 
organic", which is about $0.1 \%$ of the total agricultural research budget of US\$24 billion.

Publications on organic agriculture

The founding of the journals Biological Agriculture and Horticulture (1982) and the American Journal of Alternative Agriculture (1986, today named Renewable Agriculture and Food Systems) facilitated the publication of scientific information related to organic agriculture. In 2011, the ISOFAR journal Organic Agriculture was launched by Springer scientific publisher to meet the growing demand for scientific publications about organic agriculture research. Since organic agriculture research is currently mainly financed by public money, the organic research agenda has been influenced by the directions of the national and pan-national support programs.

In 2008, Watson et al. published a study about the status of organic agriculture research. They conducted a literature review in the Web of Science for the period 1975 to 2004 and subdivided this period into subperiods of 5 years. For the last sub-period (19992004), they found that $0.074 \%$ of all papers listed with the abstract search terms "agriculture" or "farming" dealt with organic agriculture. However, Watson et al. (2008) pointed out that many research results about organic agriculture issues were published in other sources than scientific papers, such as government reports, conference proceedings and information brochures, which are to some extent even more important for farmers and policymakers.

Siegmeier et al. (2014a, b) also analyzed the number and share of articles dealing with organic agriculture in the International Science Citation Index (ISI) of Thomson Reuters Web of Science. They conducted a topic search with the search terms "organic farm*" or "Organic Agriculture" and compared the number of organic publications (ORG) with the number of all publications dealing with agricultural topics (AGR) (Table 1). For the

Table 1 Doubling times of organic and general agricultural literature (Siegmeier et al. 2014a, b)

\begin{tabular}{llll}
\hline & \multicolumn{2}{l}{ Doubling time (2T) } \\
\cline { 2 - 4 } & $1992-2011$ & $2002-2011$ & $2007-2011$ \\
\hline $\begin{array}{c}\text { Organic agriculture } \\
\text { (ORG) } \\
\text { Agriculture (AGR) }\end{array}$ & 6.5 years & 3.4 years & 1.9 years \\
\hline
\end{tabular}

period 1977-2011, they recorded 2801 ORG publications (about 2\%) and 136,712 AGR publications. To make the development of the number of publications in different topics comparable, with total number of publications being very different, they used the doubling time as an indicator. This analysis showed that the numbers of ORG and AGR publications had very similar doubling times during the last decades. Furthermore, Siegmeier et al. (2014a, b) showed that the generally expected exponential pattern in the distribution of scientific publications (Vickery 1948) holds true for ORG publications. Exponential patterns were revealed concerning authors, countries of origin, author affiliations and journals. However, Siegmeier et al. (2014a, b) did not include the search term "organic food" so that many publications on the levels of consumers, processors and traders were not covered.

In general, research in organic agriculture claims to be more holistic compared to research in non-organic agriculture (Watson et al. 2008), because reductionist science is thought to be incapable of solving complex system problems (Huesmann 2001). Holistic approaches are also in accordance with the views of the pioneers of organic agriculture research, such as Lady Eve Balfour (1943), who claimed that "the health of soil, plant, animal and man is one and indivisible". This expectation leads to conflicts for researchers, as there is a general movement towards reductionist approaches to increase the number of publishable papers that also holds true for organic agriculture research (Squire and Gibson 1997). To cope with this problem, Watson et al. (2008) propose an approach they call "hierarchical system approach", which uses inter- and trans-disciplinary methods to gain holistic insight by a variety of smallscale (reductionist) experiments. In addition, there is a growing movement of scientists advocating for a new evaluation system of research results that goes beyond well-established bibliographic indicators to highlight innovative aspects and issues more relevant to farmers and other end users (Spaapen 2015; Wolf et al. 2015).

Organic agriculture research often places a specific area of interest into a whole systems, environmental, sustainability or livestock health and welfare context. In some projects, researchers compare the outcomes of organic agriculture systems with conventional (Watson et al. 2008). Stinner (2007) stated that the research efforts in organic agriculture have grown rapidly since the mid1990s, and he summarized these efforts under the topics soil ecology, nutrient losses, natural controls 
of insect pests and diseases, crop resistance to pests and diseases, crop and food quality, weed ecology and livestock.

\section{The base for Organic 3.0 research: future challenges of food and farming}

Although several research projects have delivered a range of insights and outcomes in the organic agricultural area, some key questions have been identified within the community. Specifically, what is the future of organic agriculture and how can research help to solve future challenges for the food and farming sector with organic measures and strategies? What will be the role of science?

The most important challenges for organic agriculture are to move from a purely agricultural perspective towards organic as an agri-food system view including the following:

1. Producing sufficient healthful, safe and affordable food for 9-11 billion

2. Reduction of pollution and greenhouse gas emissions derived from food production, processing, trading and consumption

3. Developing food chains driven by renewable energy and recycled nutrients

4. Adapting to climate change and mitigating greenhouse gas emissions

5. Protecting soils, water, air, biodiversity and landscapes

6. Taking into account current and emerging ethics, food habits, lifestyles and consumer needs

In the following sections, selected aspects of these global challenges are outlined to understand the dimension and needs for research. We focus on those aspects where scientific evidence clearly underpins the potential of innovation coming from organic agriculture. We exclude aspects of agropolicy and consumer behavior, due to the contrasting of diverse global conditions. Further, we omit internal challenges within the organic sector such as certification and guidelines. Highlighting and deepening selected aspects do ignore the interactions among most of these challenges. Global climate change, for example, strongly influences the security of food supply and the loss of biodiversity.
Feeding the world

For the period 2012-2014, FAO, IFAD and WFP (2014) estimated that worldwide, 805 million people were undernourished (consumption of fewer than $1800 \mathrm{kcal}$ per capita per day), a prevalence of $11.3 \%$. The majority of people expected to suffer from hunger live in Southern Asia (276.4 million, 15.8\%) and Sub-Saharan Africa (214.1 million, 23.8\%). Other than hunger, malnutrition, which refers to the inadequate intake of essential vitamins, minerals and other health promoting compounds, plays an important role. It is estimated that about two billion people are suffering from this hidden hunger worldwide (Grebmer et al. 2014).

However, there are currently enough calories and proteins produced globally to feed our population (FAO, IFAD and WFP 2014), but distribution is uneven. Those suffering undernourishment are not able to buy sufficient food, while others experience gross levels of food waste. Tilman et al. (2001) argue that hunger is mainly due to political and economic reasons such as armed conflicts, rural poverty, missing access to land, missing availability and affordability of food and consumption patterns.

In contrast to the problem of undernourishment, in $2013,36.9 \%$ of men and $38.0 \%$ of women had a body mass index (BMI) of 25 or greater worldwide, with a BMI between 18.5 and 25 indicating optimal weight. In developed countries, $23.8 \%$ of boys and $22.6 \%$ of girls are overweight or obese, and in developing countries, $12.9 \%$ of boys and $13.4 \%$ of girls are overweight or obese ( $\mathrm{Ng}$ et al. 2014). If the post-2000 trends continue, the global obesity rate (BMI $>25$ ) will rapidly reach $18 \%$ for men and $21 \%$ for women, and severe obesity (BMI >35) rates will reach $6 \%$ for men and $9 \%$ for women, respectively (Ezzati et al. 2016).

It is expected that the global population will grow to more than 9-10 billion people in 2050 (UN 2015b). OECD and FAO (2014) estimate that food production must increase by $60 \%$ over the same period to meet this growth, if actions are not taken to change diets, and reduce food waste (Alexandratos and Bruinsma 2012). The estimated needed increase in food production is almost twice as high as the expected population growth, which is slightly more than $30 \%$. Globally, increased production yields and resistant crops are the main targets of agricultural research and development. Genetically modified organisms (GMOs) are considered a key instrument for achieving these goals. However, genetic 
modification is not a perfect solution. GMOs make farmers dependent from external inputs, and the promises of GMOs have fallen short (Reganold and Wachter 2016; IAASTD 2009).

The majority of farmers in developing countries facing hunger practice low input-low output systems. Moving towards low input-medium output can be achieved using best practices for organic with or without organic certification. Pest and weed management in cultivation, improved utilization of organic matter sources and legumes, livestock-crop integration and improved harvest, storage and distribution structures would also improve food security (FAO 2013). Local food and consumption systems with fair conditions would inrease the access to healthy and affordable food across socioeconomic levels (IAASTD 2009).

Changes in diets and especially the rapidly increasing consumption of meat following economic growth are likely to require higher production of food than the population increase alone. Food loss and waste can be up to $50 \%$, depending on the type of food and the region of production and consumption (Gustavsson et al. 2011). According to recent estimations, around one quarter of the global food supply produced $(614 \mathrm{kcal}$ capita $^{-1}$ day $^{-1}$ ) is lost within the food supply chain from farm to fork. With best management practices and region-specific global food supply, losses could be halved (Kummu et al. 2012).

Agricultural impact on the environment

Farming activities take up $38.4 \%$ of the earth's ice-free land surface. The global land surface is about 11 billion ha. Four billion ha are used as permanent grassland (decreasing), and one billion ha are cropland (increasing) (FAO 2015a; UNEP 2014). Agriculture is responsible for significant changes in natural conditions (landscape, relief, soil, water, air, fauna and flora) and may cause environmental damage through intensive tillage, high animal densities and intensive grazing, monotonous crop rotations and the intensive (mis-)use of pesticides and fertilizers. Additionally, soil degradation and desertification are impacting production potential. Intensification has been made possible due to the low cost of finite resources and externalization of societal costs for environmental pollution. FAO (2015a) estimates capital losses from environmental degradation (natural capital losses) at US\$1.15 trillion (170\% of production value) per year.
Livestock natural capital costs (greenhouse gas emissions, degradation of natural grazing areas) are even higher, at US\$1.81 trillion (134\% of production value) per year. Seventy-seven percent of the natural capital costs of crop production occur at the farm level, with a considerable contribution from excess nutrients leaching into water, intensification of land use and pesticide pollution.

On the other side, agricultural activities may diversify the landscape and increase biodiversity and landscape quality (e.g. Scherr and McNeely 2008; Rahmann 2011). Several plant and animal species are dependent on agricultural activities. This potential of a careful and diverse agriculture to enrich the natural environment should not be neglected when the impact of agricultural activities on the environment are considered.

\section{Soil fertility and soil quality}

Worldwide, $25 \%$ of agricultural land is highly degraded, with erosion and salinization being the two most dominant forms of soil degradation (DeLong et al. 2015). The most extensive soil degradation appears in SubSaharan Africa and South Asia (Lal 2009; Bindraban et al. 2012). According to Sanchez and Suraminathan (2005), in Sub-Saharan Africa, about $75 \%$ of the total arable land (95 million ha) is highly degraded, and farmers lose 8 million tons of soil nutrients (equivalent to US\$4 billion) annually.

A review from Bhattacharyya et al. (2015) deals with the problems of soil degradation in India, estimated to be occurring on 147 million ha of land. This is a serious issue, as the country supports $18 \%$ of the world's human population and $15 \%$ of the world's livestock population, while comprising only $2.4 \%$ of the world's land area. The authors construct an extensive list of natural and human-induced causes for soil degradation, including inappropriate agricultural practices such as excessive tillage, use of heavy machinery, excessive and unbalanced use of inorganic fertilizers, poor irrigation and water management techniques, pesticide misuse and overuse, inadequate crop residue and/or organic carbon inputs and poor crop cycle planning.

Erosion, one of the dominant forms of soil degradation, removes or reduces the upper fertile layer of the soil. Montgomery (2007) estimated that conventionally ploughed agricultural fields cause rates of erosion one to two orders of magnitude higher than both the erosion rate under natural vegetation and the soil regeneration 
rate. In India, China, Iran, Israel, Jordan, Lebanon and Pakistan, yields have been reduced by $20 \%$ due to erosion (Dregne 1992), while a worldwide productivity loss close to US $\$ 400$ billion annually is estimated (Pimentel 2006). Soil erosion is a special challenge for organic agriculture, since conventional ploughing and intensive soil tillage is often required to control weeds without herbicides.

Nitrogen $(\mathrm{N})$ and phosphorus $(\mathrm{P})$ losses contribute to a range of effects, such as eutrophication, air and water pollution, climate change and stratospheric ozone depletion (Erisman et al. 2013). High animal densities are associated with a decoupling of animal and crop production, leading to excessive fertilizer applications in cropping systems not designed to conserve nutrients (Bleken et al. 2005). These challenges contribute to the export of $\mathrm{N}$ and $\mathrm{P}$ into coastal oceans which leads to eutrophication, algal bloom, hypoxic conditions and biodiversity loss in coastal waters. The use of $\mathrm{P}$ fertilizers tripled between 1960 and 1990 (Millennium Ecosystem Assessment 2005). Human population and urbanization along waterways exacerbated the impact of fertilizer use increases, with sewage and industrial effluents adding to the nutrient overload from agriculture (Rabalais et al. 2009). Increasing amounts of nutrients over several decades have been transferred from land to the sea (Seitzinger et al. 2002), depriving coastal populations of their marine-based livelihoods. Seen in light of the large demand for $\mathrm{N}$ and $\mathrm{P}$ globally, the badly balanced distribution of these plant nutrients on a global scale, driven by industrialization of agriculture, is alarming.

In dry areas, soils are degraded by salinization, the contamination of soil with salt, derived from evaporation rates being above precipitation. This issue hinders plants ability to take up sufficient water to meet physiological needs. Some of the hot spots of salinization are in the USA, Pakistan, Iraq, Australia and China. Worldwide, 34 million ha of land are affected (FAO 2011a, b), increasing by 1.5 million ha year ${ }^{-1}$, e.g. due to changing climatic conditions. The resulting decline in production is estimated to cost US $\$ 11$ billion a year (Wood et al. 2000; FAO 2015a).

Organic agriculture is not immune to the problems of soil degradation. Many organic agriculture systems, especially in the developed world, make intensive use of tillage, especially to control weeds and to incorporate organic amendments (Bàrberi 2006). Raviv (2010) reported that the most important field of research in organic horticulture should be the identification of novel and efficient methods for weed control that have no negative effects on system sustainability, especially on soil quality parameters. The author also showed that improved energy efficiency typical of organic cropping systems is often offset by increased tillage or other methods for weed control, e.g. thermic. Consequently, energy efficient strategies to control weeds need to be further developed, including no-till and reduced tillage cropping systems.

\section{Biodiversity loss}

In 2005, the results of the Millennium Ecosystem Assessment (MEA) were published. The synthesis report on biodiversity pointed out that in the past 50 years, changes in biological diversity were more rapid than at any other time in human history. In general, genetic diversity across many species has declined globally, especially among domesticated species. This may result in significant future problems for the agricultural sector, as reduced genetic diversity lowers the resilience and adaptability of species to natural- or human-induced disturbance (MEA 2005). Rockström et al. (2009) concluded that the rate of biodiversity loss today is far beyond the planetary boundaries for a safe operating space for humanity.

MEA (2005) further found that habitat change, climate change, invasive alien species, overexploitation of species and pollution are direct drivers of biodiversity loss and change in the provision of ecosystem services worldwide. Agriculture is considered a major driver of these problems, especially through habitat or land use change and nutrient loading. The impact of agricultural (mis)management on loss of biodiversity and ecosystem services is important considering that $38.4 \%$ of the Earth's terrestrial surface is covered by cultivated systems.

\section{Climate change}

Worldwide, between 1880 and 2012, the temperature at the land and ocean's surfaces increased on average by $0.85{ }^{\circ} \mathrm{C}$. It is accepted by scientists that the increase of greenhouse gases (GHGs) in the atmosphere due to human activities is the cause of global warming (IPCC 2014a, b). Human activities have caused a level of GHGs in the atmosphere that has not occurred for over 800,000 years. In 2010, $49 \mathrm{Gt}$ of carbon dioxide 
equivalents $\left(\mathrm{CO}_{2} \mathrm{eq}\right)$ were emitted worldwide (IPCC 2014a, b).

In 2010, emissions of important GHGs, dinitrous oxide and methanefrom agriculture were estimated to be 5.2-5.8 $\mathrm{Gt} \mathrm{CO}_{2}$ eq year ${ }^{-1}$ (FAOSTAT 2013; Tubiello et al. 2013), which is about $10 \%$ of the global total. Enteric fermentation and release from agricultural soils represent the majority of this, about $70 \%$, followed by paddy rice cultivation (9-11\%), biomass burning (6$12 \%)$ and manure management (7-8\%). The largest shares of emissions from enteric fermentation (75\%), deposited manure (80\%), synthetic fertilizers (70\%) and paddy rice production (94\%) were from developing countries. It should be noted that the above-mentioned global figure of GHG emissions does not include inputs from land use change, forestry and activities that change the status of peat land. When including these, agriculture, forestry and other land use accounted for $24 \%$ of global GHG emissions in 2010. The resulting figure of about $12 \mathrm{Gt} \mathrm{CO}_{2}$ eq year ${ }^{-1}$ does not take into account upstream factors such as the production of synthetic fertilizers or fuel combustion for farming and transport. Bellarby et al. (2008) calculated these amounts at $0.059-0.257 \mathrm{Gt} \mathrm{CO}_{2}$ eq year ${ }^{-1}$ for the use of farm machinery and 0.284 to 0.575 for the production of fertilizers. (Worldwide, agriculture is consuming 11 exajoule (EJ) of energy annually and this amount is expected to increase by 0.8 to $2.9 \%$ annually between 2000 and 2030 (Price et al. 2006)).

Fiala (2008) projected that by 2030 , the global emissions of GHGs from the production of chicken, pork and beef will reach $1891 \mathrm{Gt} \mathrm{CO}_{2}$ eq year ${ }^{-1}$. Furthermore, Fiala (2009) showed clear differences between GHG emissions from the production of potato, apple and asparagus being $0.12,0.14$ and $0.18 \mathrm{~kg} \mathrm{CO}_{2} \mathrm{eq} \mathrm{kg}^{-1}$, respectively, compared to those resulting from the intensive production of chicken, pork and beef emitting $0.49,1.72$ and $6.71 \mathrm{~kg} \mathrm{CO}_{2} \mathrm{eq} \mathrm{kg}^{-1}$, respectively.

Stavi and Lal (2013) discussed the potential effects of climate change on agriculture and concluded that climate change impacts on agricultural productivity are expected to vary significantly depending on geographical region. In humid temperate regions, higher temperatures and $\mathrm{CO}_{2}$ fertilization effects may benefit agriculture; however, the expected rise in the number of extreme weather events will restrict time windows for fieldwork operations and increase risks for agricultural production. Nevertheless, humid temperate regions will be better off than semi-arid regions closer to equator, where the expected increased frequency of extremely warm periods and droughts will increase soil degradation and leave large areas unproductive. Intropic and subtropic regions, the consequences of warming and shifts in precipitation, are hard to foresee, and declines in crop yields are projected to range between 3\% and almost total failure (Deryng et al. 2014) Climate change will also affect the performance of semi-natural ecosystems such as pastures and the emergence, spread and distribution of livestock diseases, insect pests and invasive plant and animal species.

To keep global temperature under the widely agreed critical value of $+2{ }^{\circ} \mathrm{C}$, GHG emissions in all sectors need to be reduced by 40 to $70 \%$ by 2050 , compared to 2010 values, and emissions will have to be around zero or even below by 2100 (IPCC 2014a, b).

Changing ethics and habits

Farmers and consumers are two of the key players in agricultural systems. Awareness of the social situation of farmers and farm workers, especially small-scale farmers in developing countries, is an important factor for stabilizing societies. Consumer interests and choice patterns tie in with the ethical treatment of producers, as they have expectations and perceptions of how farming should be done. The process qualities of the food chain are a crucial issue in the relation between producer and consumers. Ethical issues such as environmentally sound production, high animal welfare and fair working conditions are a key component in delivering truly sustainable food.

\section{Farmer and farm worker conditions}

The socioeconomic and social state of farmers and farm workers heavily depend on their working conditions as well as on the level of their wages and strength of their social support structure.

On the global level, four main types of farms with innumerable variations can be distinguished. One category includes industrially managed large-scale farms. These farms are owned either by large estate holders or by companies. Typical examples are big producers of soybean and grain in North and South America and companies that have emerged from former state-owned agrarian companies in China and Russia. Large-scale farms rely on an intensive division of labor. They are managed hierarchically and use costly machinery and 
technical assistance. The bulk of work is done by skilled and unskilled workers who are supervised by agricultural engineers and technical specialists. Corporate management is carried out by the owner of the company or by managers. Problems mainly arise for the workers, who are often paid poorly, do not have adequate social safeguards and may be reliant on seasonal work. In organic agriculture, this type of farm is an exception although there are no valid statistics on their frequency among different farming systems. However, structural changes and increasing consumption may lead to a rise in the number of large-scale, industrial farms also within organic agriculture. This we do not know! And is a little bla-bla.

The second category of farms include industrially managed family farms, common in Western Europe. Here, agricultural work is done by family members, with few wageworkers or agricultural contractors. Problems within this farm type mainly arise from competitive disadvantages in a retail sector which is rapidly centralized. For example, in 2012, the five most important food retailers in 24 European countries had combined market shares between 27 and 82\% (Statista.com 2015). This centralization puts pressure on the family farm structure, reducing their income. This structural transformation of the farming sector has been ongoing in developed countries for several years, with no signs of slowing down (OECD and FAO 2015).

The third category are medium-scale family farms in developed countries seeking to overcome problems by regional marketing and direct contact to consumers and processors. Their strategy is to shorten the food chain often combining this strategy with the production of higher value products fresh or processed. This farmtype strategy reassembles the type of organic pioneer farms representing a diverse production in mixed farm concepts or horticulture.

The fourth category of farms on the global scale includes non-industrialized medium and small-scale farms. When examining types of farms throughout the globe, this type of farm is the most frequent. Small-scale farmers often face harsh working conditions, generate low income and have few social safeguards. The situation of small-scale farmers is closely inter-linked with the challenge of feeding the world. Worldwide, 2.6 billion people ( 2.5 billion in developing countries) live mainly from agriculture (FAO 2012). Small-scale farmers farm on average 2.4 ha in Sub-Saharan Africa and 1.8 ha in Southeast Asia (Deininger et al. 2011;
FAO 2013). Although there are many small-scale farmers in Africa, the import surplus for agricultural products stood at US\$22 billion in 2007 (OECD 2014), indicating that African farmers do not feed their own continent. In these circumstances, farming is put at further disadvantage through political uncertainties, missing rules of law, missing legal certainty and generally poor management. Furthermore, small-scale farmers sometimes have to compete in global markets. One prominent example is the export of chicken meat from Europe to Africa, which considerably influences local markets and value chains. Other mechanisms destructive for local sustainable economies are worldwide speculation with agricultural products, the expansion of free trade agreements, the land use competition between food, feed, fibre and fuel and land grabbing (IAASTD 2009).

\section{Ethical aspects of farming}

In his book, "The Imperative of Responsibility: In Search of an Ethics for the Technological Age", Jonas (1984) carves out the ecological responsibility of humans to protect natural resources. This responsibility arises from the fact that humankind relies on natural resources and the value intrinsic worth of pristine nature. As all farming systems work with and depend on natural resources, this responsibility has to be assumed when discussing agricultural development. Consequently, organic agriculture has to realize a multifunctional approach that entails the production of sufficient highquality food, feed, fibre and fuel as well as a fifth "f" standing for "further deliveries" (Köpke 2016a), i. e. ecological services as well as animal welfare.

The philosphy and leading thoughts of Jonas (1984) and others helped give rise to the animal ethics during the last decade. While there is a general consensus that humankind must bear responsibility for animals (Nida Rümelin 2005). In parallel to these theoretical discussions, questions of animal welfare have received increasing awareness in many societies during the last decades (Oppermann and Rahmann 2009).

In Germany, for example, the debate on how livestock should be kept was the reason why the Scientific Advisory Board for Agricultural Policy of the Federal Agricultural Ministry published an expert opinion to find ways leading to a socially accepted form of livestock farming (BMEL 2015). 
Besides ethical considerations about environmental responsibility and animal welfare, in recent years, discussions have been raised on how partners along the value chain of the farming and food sector should interact in a socially fair attitude. These discussions, which relate to all sectors of production, processing and trading, became more intense after the economic crisis in 2008. As professionalization took place in the organic agriculture sector during the phase of Organic 2.0, structures changed from small-scale to long, centralized value chains. Within these newly establishing structures, maintaining transparency, fairness and cooperation between market actors (values that organic agriculture relies on) became more and more complicated and therefore a topic of controversy among actors of the market chain (Rahmann et al. 2009).

\section{Changing attitudes of consumers}

Growing consumer awareness of environmental issues and animal welfare has led to higher organic market share in several countries. A recent study from Germany (BMU and UBA 2015) showed that from 2000 to 2014,14 to $35 \%$ of the respondents cited environmental conservation as one of the two most pressing issues facing the country. Concurrently, about $30 \%$ found environmental conservation to be in direct conflict with job creation (BMU and UBA 2013), and about 60\% were only willing to take action in conserving the environment if their living standard would not be negatively influenced (BMU and UBA 2008). Analogue conflicts are present for the consumption of organic products: People express larger interest than they actually convert to practice. In the UK, for example, $70 \%$ of consumers claim to buy organic products, but the market share of these products is only about $1.5 \%$. This demonstrates an attitude-behavior gap, with most consumers buying organic products only sporadically (Soil Association 2009; Pearson et al. 2011; Harvey and Hubbard 2013). While there is a general receptivity of consumers to organic food, the market share of products is still low (Pearson et al. 2011; BÖLN 2013), however, rapidly increasing by 5-10\% annually (Willer and Lernoud 2016).

The general trend of increased meat consumption worldwide will pose substantial challenges for all future farming systems. Based on FAO data, Henchion et al. (2014) found aggregated meat consumption increased from 175,665 tons in 1990 to 278,863 tons in 2009 (ca. $+60 \%$ ), and this increase cannot solely be explained through growing populations, as per capita consumption also increased during the same period, from 33.7 to $41.9 \mathrm{~kg}$ annually. The trend towards consumption of white meat, already observable during the period from 1990 to 2009 (Henchion et al. 2014), will probably continue in the future, and by 2022 , poultry is expected to overtake pig meat as the most consumed meat in the world (European Commission 2012). The annual growth worldwide of meat consumption is expected to be around $1.7 \%$ by 2021 (OECD and FAO 2013), and this growth will mainly be driven by increased consumption in emerging and developing countries (Thornton 2010). It is predicted that the demand for meat will double in these countries by 2020 when compared with 1997 levels (Rosegrant et al. 2001). It remains an open question whether this increase may be balanced by the rapidly increasing interest in vegetarianism and reduced meat consumption in western countries (Quinn 2016), supported by climate change mitigation.

Food quality and health

Consumers buy organic food because they believe it is more environmental friendly, healthier and tastes better than conventionally produced food (Tauscher et al. 2003; Torjusen et al. 2004; Verbeke and Lahteenmaki 2009; Stolz et al. 2011; Kriwy and Mecking 2012; Pino et al. 2012; Zanoli and Naspetti 2002; Zagata 2012). Several authors analyzed the motivations of organic consumers and found that while most consumers are not well educated about organic agriculture, they believe that organic products are better and healthier due to reduced pesticide risks and higher ethical values. Since improved taste is often related to freshness, many consumers believe organic food to have a higher quality than conventional (Johannsson et al. 1999; Padel and Foster 2005; Hughner et al. 2007; Naspetti and Zanoli 2009; Hjelmar 2011). Comprehensive studies have shown clear advantages for several parameters describing a higher product quality of organic produce compared to products derived from mainstream agriculture (Baker et al. 2002; Benbrook 2015). The limited availability and uptake of nitrogen is considered as responsible for the often higher contents of secondary metabolites as beneficial ingredients in organic products compared to conventional (Mozafar 1993; Brandt and Molgaard 2001; Köpke 2005). 
To help unify consumer perceptions of organic with actual organic system management, the European Union put in place regulations for organic production and processing (EC 2007; EC 2007). Nevertheless, Kahl et al. (2010) showed that there seems to be a gap between consumer expectations and what can be guaranteed according to food quality through regulations and standards. For this reason, the organic sector must keep high quality standards and provide verifiable and realistic information about in which value-added categories organic food is supported by substantial research and in which categories the support is not (yet) evident. In addition to the authentication and regulation of farming practices, transparency on realistic organic benefits will safeguard organic integrity throughout the supply and consumption chain (Kahl 2012).

\section{Contribution of organic agriculture in addressing future challenges}

Thirty-six invited scientists from around the world with expertise in a wide variety of disciplines discussed the challenges for future food systems and the role which organic agriculture can play to solve the problems when they met near Goesan in South Korea from September 20-22, 2015, in conjunction with the first ISOFAR International Organic Expo. In four closed sessions, the issues of feeding the world, reducing the impact of humans on the environment, ethical issues of food systems and food quality were discussed.

Feeding the world

\section{Yield gap and food waste}

The average worldwide yield gap between organic and conventional agriculture is estimated to be between 20 and $30 \%$ with high standard deviations $( \pm 21 \%)$ (Raynolds and Wachter 2016; Seufert et al. 2012; Niggli 2014; Grinsven et al. 2015). Furthermore, de Ponti et al. (2012) found that the yield gap increases when calculated on broader levels, such as the farm or regional level, and that the gap tends to increase with increasing conventional yields. This may be a reason for the observation that the yield gap is particularly marked in developed countries where intensive conventional agriculture systems are high yielding, and that in recent decades, the yield increase per hectare in studies from developed countries, such as Germany, has been lower for organic than conventional crops (Noleppa 2016).

While de Ponti et al. (2012) and Seufert et al. (2012) concluded that there was not a sufficient number of studies to support or reject the possibility that organic can produce comparable yields to conventional systems, Reganold and Wachter (2016), by assessing 40 studies, came to the conclusion that organic agriculture can significantly contribute to solving future food problems, particularly in low input-low output systems in developing countries, by outperforming local conventional systems.

Thus, the topic "feeding the world through Organic Agriculture" needs to be applied in different ways for different regions of the world and for different intensities of farming systems. For example, it has been suggested that organic agriculture can only generate sufficient returns in Sub-Saharan Africa to achieve broad adoption if special incentives such as subsidies or guaranteed premium prices are introduced (Toenniessen et al. 2008).

Alternatively, Grinsven et al. (2015) advocate for compensation of a sustainable extensification of agriculture in the Netherlands and Northern Europe, to be balanced by a sustainable intensification elsewhere in currently low-yielding areas. The authors argue that conversion to a "demitarean" diet, halving the standard portion of meat consumed in a regular meal, in the EU27 can be provided by large-scale conversion to organic agriculture while at the same time reducing demand for agricultural land outside the EU by about 100 million ha.

While sustainable yield improvement and stabilization of yields seem achievable for developing countries through applying organic agricultural methods, closing the yield gap between organic and conventional systems in developed countries could be seen as secondary to reducing food waste. Currently, up to $35 \%$ of food initially produced is lost or wasted along the food supply chain, and another $17-25 \%$ is wasted at the consumer level (Gustavsson et al. 2011).

Thus, the discussion about yield gaps in developed countries cannot be uncoupled from discussions about food wasting, changing diets and global production balances. Additionally, Holt-Giménez et al. (2012) argue that the current worldwide food production is already sufficient to feed ten billion people and that hunger is caused by poverty and inequality rather than a lack of production. 
The role of livestock

The role of livestock is key in addressing the ability of organic to feed the world. Since about $80 \%$ of total farmland is non-arable, i.e. grassland and pastures, ruminants do play a key role for sustainable land use entailing meat, milk and fibre production with restriced competition for human food. Furthermore, grasslanddominated feeding of ruminants relativizes the aspects of climate change impacts by ruminants. Thus, livestock will play an important role in agri-food systems of the future, but current livestock density needs to be reduced due to scarcity of resources, especially in developed countries. In developing countries, on the other hand, there is a need for sustainable small-scale animal production systems, particularly systems that rely on livestock for nutrient recycling or as a backstop in times of economic uncertainty. Livestock operations design is especially important in fragile environments, where animal grazing must be controlled and manure must be gathered for recycling where appropriate.

It is also important to address what amounts of animal products are optimal from a dietary perspective. Research is needed on effective strategies to reduce the consumption of animal protein and modeling regionalized solutions to maximize food availability and nutrient efficiency.

\section{Nutrient cycling}

To produce sufficient amounts of food, nutrients are required for fertilization and maintenance of soil fertility. On farms without animal integration, solutions for nutrient recycling from urban areas to agriculture will be critical for future sustainability and food security. There is a need for new P fertilizer sources that are acceptable in organic agriculture (Løes et al. 2016), and nitrogen management is important, because fertilizer overuse and mismanagement of $\mathrm{N}$-fixating legumes may result in environmental pollution. Incorporating legumes into crop rotations has been asserted as essential for crop management systems that aim at enhancing sustainability and buffering against the dependence on mineral $\mathrm{N}$ fertilizer and of high energy input (Vance 2001). Digesting organic materials, including crop residues and green manures, for energy production, provides an interesting opportunity for optimizing $\mathrm{N}$ supply in organic farming systems (Frøseth et al. 2016; Pugesgaard et al. 2014), since the traditional mulching of green manures may lead to significant $\mathrm{N}$ losses. Excessive use of agricultural fertilizers, and the current treatment of human sewage, commonly leads to eutrophication of water bodies and contribute to GHG emissions, while resources of phosphate rock are diminishing and dependence on $\mathrm{N}$ fertilizer is increasing (Paulsen et al. 2016). This adds on to the need for improving recycling of nutrients and organic matter from field via fork and back again to agricultural production. Permitting the use of struvite and calcined phosphate, as recently proposed by the expert group for technical advice on organic production (European Commission 2016), will significantly change the nutrient supply to organic agriculture, provided pathogens and contaminants are controlled satisfactorily. Recent studies (Løes 2016) have shown that a majority of stakeholders from the organic sector are positive towards increased utilization of human excreta in organic farming. Human excrements are basically freely available organic matter and nutrients, which can be used for energy production and fertilization. It can be used to produce methane, compost and even energy through incineration. This valuable resource needs to be recycled back into the system and applied to the soil. However, we also need to address the pathogen problem. Some research has been done showing that plants are good at mitigation for heavy metals (Kumar and Dushenkov 1995) and composting can be used for pathogen elimination, but more research is needed in these areas.

Reducing the impact of agricultural activities on the environment

There is no doubt that all farming systems affect nature and the surrounding environment. Since agriculture can both preserve biodiversityand destroy biotopes, there is an option to reduce negative impacts while maximizing ecosystem services. Organic agriculture addresses this challenge, but while it is considered environmentally sound when best practices are followed, it still has room to improve (Rahmann et al. 2009; Rahmann and Aksoy 2014; Reganold and Wachter 2016). Precision farming tools should be adapted to organic farming needs to combine the "land sparing" vs "land sharing" concepts on the field scale. Fossil energy and available external nutrient inputs need to be replaced by renewable and recycled resources to avoid further land use changes and other detrimental environmental effects. 


\section{Maintaining and improving soil fertility}

As discussed in "Nutrient cycling", recycling of nutrients from society back to organic farming systems will be required in the long term, as shown by several studies where organic farming systems tend to decline in soil nutrient concentrations (e.g. Gosling and Shepherd 2005; Haas et al. 2007). Mixed farming systems, where nutrients are cycled within the system via animal manure, are well known for good quality of soil organic matter, active soil biology and favorable soil structure (Mäder et al. 2002). Lal (2009) and Bindraban et al. (2012) highlight that several techniques commonly used in organic agriculture contribute to restoring degraded soils, such as no-till farming (Moos et al. 2016), using light machinery, mulching, cover cropping, integrated nutrient management, residue management, crop rotation, planting crop mixtures, manure application and use of $\mathrm{N}$-fixing plants. These techniques can be considered a starting point for developing sustainable systems to restore degraded soils (Bindraban et al. 2012). Bhattacharyya et al. (2015) proposed to work on solutions at the level of watersheds, as the various elements of these units are subject to relatively similar climatic conditions and therefore similar management measures show promise in mitigating environmental changes.

Organic agriculture contributes to conservation agriculture through its adoption of diversified crop rotations and cover crops, but it lags behind in the adoption of reduced tillage systems. However, interest by organic farmers in conservation tillage is increasing in both arable (Peigné et al. 2007; Peigné et al. 2016) and vegetable cropping systems (Canali et al. 2013). Recent research projects (e.g. www.tilman-org.net, http://coreorganicplus.org/research-projects/soilveg/) have shown that appropriate crop rotation and cover cropping designs, reduced tillage as well as occasionally reduced tillage or occasional direct seeding have the potential to preserve yield levels and prevent build up of aggressive weed communities (Bàrberi et al. 2014; Cooper et al. 2014; Moos et al. 2016). This pathway is likely to result in organic agriculture systems becoming more resilient and environmentally friendly. In Mediterranean regions, conservation tillage systems with cover crops could have similar potential in the control of weeds and provision of additional ecosystem services such as soil temperature control and the conservation of water and energy. Such systems are well adapted to organic vegetable growing, which may contribute to both food security and farmer revenue (Canali et al. 2015; Moos et al. 2016).

Redesigning organic farming systems is necessary for Organic 3.0. Besides restricted input, inputs should be sustainably produced and applied correctly and precisely. Taking a redesign approach based on agriecology gives us the chance to shape future farming systems and food supply chains to overcome issues created by the widely implemented "substitution" approach, where organic inputs are substituted for conventional ones.

\section{Preserving biodiversity}

Several studies have been conducted on the effect of organic agriculture on biodiversity (Bengtsson et al. 2005; Hole et al. 2005). The latest meta-analysis by Rahmann (2011) and Tuck et al. (2014) revealed an overall positive effect of organic agriculture on biodiversity, with an average $30 \%$ increase in species richness. Results have been robust over the past 30 years. The authors point out that the effect varies with the organism group and crop studied, the positive effect on biodiversity is greater in landscapes with higher landuse intensity and studies conducted so far are heavily biased towards the developed world, especially Europe and North America. An ongoing debate concerning the positive effect of organic agriculture on biodiversity is about the costs at which this benefit is achieved.

Gabriel et al. (2013), for example, argue that increased biodiversity is correlated almost proportionately with decreasing yields and therefore more agricultural land would be needed to produce sufficient food supply, which in the end might cause even more negative impacts on biodiversity. At this point, the discussion relates to the challenge of how to feed the world. In this respect, it is useful to introduce the concept and approach of functional agri-biodiversity without loosening overall diversity which in its uncovered elements and interactions may deliver further currently unknown ecological services (Köpke 2016b, 2017).

Despite the many definitions of functional agribiodiversity in the scientific literature (e.g. Pearce and Moran 1994; Gurr et al. 2003; Clergue et al. 2005), it is most appropriate to consider functional biodiversity as the part of total biodiversity composed of groups of elements (at the gene, species or habitat level) and their interactions able to provide the same agri-ecosystem service driven by within-group diversity (Moonen and 
Bàrberi 2008). More recently, Costanzo and Bàrberi (2014) identified three functional biodiversity categories (identity, composition and diversity) and proposed that linking crop traits to agri-ecosystem services should facilitate the identification of suitable biodiversitybased options for farmers and policymakers. From a more ecologically based perspective, a similar view has been recently proposed by Wood et al. (2015). A functional, trait-based approach should highlight the benefits that organic agriculture can take from and deliver to biodiversity and contribute to the development of more sustainable and resilient organic agricultural systems (Bàrberi 2015).

A well-managed future organic agri-ecosystem can maintain or even increase biodiversity at the farm level and outside the farm. Besides, agriculture can make wise use of agri-biodiversity to increase its sustainability and resilience. Agriculture can support biodiversity ("A for B") and biodiversity can support agriculture ("B for A") (Bàrberi et al. 2010; Erisman et al. 2016). However, the importance of balancing these two views is rarely considered (Altieri 2004). This is due partly to the different importance given to them by ecologists and agroecologists and partly to the lack of a clear definition of agri-biodiversity (Moonen and Bàrberi 2008).

The biodiversity issue is often addressed in overly broad terms. Since there is no clear relationship between the biodiversity and the expression of (agro) ecosystem services (Bengtsson 1998; Wood et al. 2015), a clearer framework highlighting the potential of biodiversity to support agri-ecosystem services of whatever kind is needed (e.g. Erisman et al. 2016). This would also shed light on the likelihood that provision of production and non-production-oriented agri-ecosystem services is possible. The role of diets shaping biodiversity in production systems also needs to be evaluated (FAO 2012).

\section{Mitigating and adapting to climate change}

Agricultural activities, also within organic agriculture, contribute to climate change, which has significant and usually negative implications for agricultural production. Even subtle changes to the climate can have drastic effects on farming operations, and a general consequence of climate change is that extreme weather conditions appear more often (e.g. Hov et al. 2013). Agrifood production systems need to become more resilient to extreme weather conditions and influxes of pests and diseases. Organic agriculture has the potential to mitigate and adapt to climate change along three main features: farming system design, cropland management and grassland and livestock management (Scialabba and Müller-Lindenlauf 2010; Huelsbergen and Rahmann 2013).

Adaptation is a key factor that will shape the future severity of climate change impacts on food production. Agri-ecosystem adaptation is obtained through a number of combined strategies, such as the sustainable use of water resources, soil organic matter management and the diversification of farming systems (Mijatovic et al. 2013a, b). Recently, Diacono et al. (2016) discussed how a suite of strategies (i.e. hydraulic arrangement, crop rotations, cover crops and living mulches, use of organic soil conditioners) can be complementarily combined to design cropping systems for long-term climatic change adaptation in organic farming.

In organic agriculture, the use of external inputs is lower and thereby emissions of GHG are reduced per unit of land when compared to high-input conventional systems. However, there is more variability in GHG emissions per unit organic product, and studies have found higher, lower or equal emissions compared with corresponding conventional systems (Tuomisto et al. 2012). This implies that there is a need to improve current organic practices to achieve higher productivity per unit of land and higher $\mathrm{N}$ use efficiency per unit product. As a result of reducing external inputs, the total energy use per product unit has been shown to be on average $15 \%$ lower in organic agriculture in a study conducted in the UK (Ministry of Agriculture Fisheries and Food of the United Kingdom 2000; Huelsbergen and Rahmann 2013; Erisman et al. 2008; Rahmann et al. 2008).

Reduction of GHG emissions can be achieved by integrated livestock management. For example, in the EU, livestock units must not exceed 2 units per hectare, which is equivalent to $170 \mathrm{~kg} \mathrm{~N}$ per hectare and year, thereby tailoring manure input to plant uptake capacities. Furthermore, case studies have shown that the emissions from milk and beef production can be significantly reduced by keeping combined milk and beefyielding breeds (Scialabba and Müller-Lindenlauf 2010).

The restoration of degraded land has mitigation potential by increasing soil carbon sequestration. Strategies to restore degraded land are congruent with organic agricultural approaches such as crop rotations, use of cover crops and mulches, agroforestry, manuring and 
other application of organic amendments. In this way, organic agriculture may also help in improving livelihoods in dry areas.

The sequestering of carbon in organically managed soils has considerable potential (Gattinger et al. 2012), as sequestration is currently the only realistic way to rapidly remove $\mathrm{CO}_{2}$ from the atmosphere. Niggli et al. (2009) calculated that global farmland has a carbon sequestration potential of $2.4 \mathrm{Gt} \mathrm{CO}_{2}$ eq year ${ }^{-1}$ if converted to organic agriculture and managed for an extended period. The global carbon sequestration potential by improved pasture management practices was calculated to be 0.22 tons $\mathrm{C} \mathrm{ha}^{-1}$ year $^{-1}$ and organic livestock keeping is known to maintain such grasslands (Watson et al. 2000). However, the level of soil organic matter does not increase indefinitely but reaches a certain equilibrium (Jonston et al. 2009). Thus, carbon sequestration in soils is limited and cannot be the only solution.

Methane $\left(\mathrm{CH}_{4}\right)$ emissions from enteric fermentation are especially relevant in developing countries. While the $\mathrm{CH}_{4}$ emissions per product unit in conventional agriculture systems are controlled via the use of high energy feedstuffs in developed countries, this seems not to be the way for developing countries (Huelsbergen and Rahmann 2013). Instead, improving management, feeding, breeding and disease control are likely to be the keys to higher yields and enhanced animal longevity in these regions. In turn, there is a reduction in emissions per product unit (Pretty and Hine 2001). Whether organic agriculture in developed countries should use high proportions of high-energy feedstuff to reduce emissions per product unit is still a subject of discussions (Scialabba and Müller-Lindenlauf 2010) since the production of such crops carries a significant carbon footprint. Irrespective of this discussion, methane emissions from organic livestock systems can be reduced by about $10 \%$ (under European conditions) through increased longevity of animals. Furthermore, methane emissions from manure can be significantly reduced by fermenting the slurry in biogas plants (Müller-Lindenlauf 2009) or protecting compost windrows with a fleece cover (Sommer 2001).

However, recent studies have shown that this benefit could be counteracted by methane emissions during storage and spreading of compost and manure, implying the importance of improved management of this potential important nutrient and energy resource (Daniel-Gromke et al. 2015; Rodhe et al. 2015).
Contribution of organic agriculture to fulfilling ethical values

Support of mixed-scale farms is of vital importance for Organic 3.0, because the "Eden narrative" (Oeld-Wieser and Darnhofer 2009) of small farmers, butchers and groceries working together in harmony does not always correspond with modern market structures. On the other hand, judgements that small-scale farmers are morally superior and large-scale companies are less moral and are not reasonable.

In accordance with the agri-ecological approach, implementation of social components in the redesign process is necessary. While there are significant differences in working conditions and training systems among large industrial farms, middle-sized family farms and smallholdings, cooperation is a major challenge across the whole organic sector (Reissig et al. 2015). Increased cooperation among farmers, processors and retailers is one of the most critical steps for organic agriculture (Wägeli and Hamm 2015), and social issues related to ethical principles, especially fairness, are highly relevant in the context of this cooperation (Hamm et al. 2016). While collaboration is critical across scales, the ability of large and small actors being able to cooperate in a fruitful manner remains challenging.

In recent years, it has become clear that the longstanding mixture of small and big actors will likely not survive in the future. Large conventional food companies have entered the organic sector in both developed and developing countries (Howard 2013), and small organic companies have grown large, with national market dominance and centralization as a common consequence.

The substantial decrease in the number of small farms puts pressure on family farms, especially in Europe and the USA.

Support for medium-sized organic operations may result in market dynamic facilitation positive social development. Specifically, strong positive social relations between farmers and consumers and coordination between organic agriculture and policies that support the environment, living countrysides, tourism and cultural heritage in rural areas may be fruitful to achieve a longstanding growth of organic acreage. Diverse market channels benefit both producers and consumers (Aertsens 2011) and act against widening price margins (Kuosmanen and Niemi 2009). The most fruitful cooperation between stakeholders and consumers is based on 
co-innovation (Chathoth et al. 2013) and co-creation (Grönroos 2011).

Further, as recent case studies have demonstrated, a "perspective of equity, of acquiring autonomy and of promoting human development" has been realized in some mixed structures, where small family farms have cooperated with industry partners (Blanc 2009). Such experiences remind us that the organic movement has to avoid a too narrow or one-dimensional analytical framework. Small-scale farmers can be supported and yields can be increased when local farmers are organized, active consumer support is mobilized, agronomy is supported by by technical advice and researchers and the general public maintain involvement (Blanc 2009).

Meeting the integrity of the food chain

Most consumer expectations regarding the sustainability of food products are focused on the process of food production rather than the end product. It is therefore difficult for consumers to identify products that fulfill their expectations, because there is little transparency between on-farm practices and product appearance in retail. Certification is a means for gaining consumer trust in the integrity of the food production process and addressing this information disparity (Jahn et al. 2005). The labeling of certified products enables consumers to make informed buying decisions (Golan et al. 2001), and policies associated with certified products have helped supply meet demand while maintaining reasonable organic food prices (Thogersen 2010). Political support, e.g. in the EU, has been crucial for defining the future of organic food systems in many developed areas. It is uncertain if this support will continue in the future, and this uncertainty may have an impact on prices and standards (Zanoli et al. 2012; Barabanova et al. 2015).

There is no doubt that the ethical and cultural dimension of food systems, such as purchasing habits, processing, preparation and eating behavior, has a significant impact on food systems (Naspetti and Zanoli 2014). For example, consumer interest in the role of livestock has given rise to discussions about animal welfare and vegetarian diets. Similarly, conversations about how fast food culture is changing local food habits and systems, particularly for younger generations, have highlighted the need to train and inform the public about food production, healthy diets and sustainable living habits.
Product quality and human health

Changes in consumption patterns is a crucial issue in the transformation to sustainable food systems (Tauscher et al. 2003). Consumption patterns of organic consumers are currently closer to the sustainable diet concept of the FAO than the patterns of non-oragnic consumers (Kesse-Guyot et al. 2013). Because there is a feedback loop with diets playing a central role in shaping food systems and food systems shaping diets, the question of organic as a sustainable and healthy diet is an essential topic that must be addressed in parallel to sustainable organic production.

If we define the healthfulness of food by its nutritional quality and lack of pesticide residues (Smith-Spangler et al. 2012), there is strong support from the literature based on the possible negative effects of non-organic food on humans due to pesticide residues (Hauser et al. 2015; Blair et al. 2015), GMOs (Vendomois et al. 2010), antibiotic-resistant bacteria (WHO 2011; SmithSpangler et al. 2012), veterinary drug residues (FAO $2011 \mathrm{a}, \mathrm{b})$ and food additives such as colorants (Mpountoukas et al. 2010). Food safety is among the important reasons to buy organic food (Hemmerling et al. 2015).

Organic agriculture and food production are described as following a more holistic approach (Codex Alimentarius EC 2007; Levidow et al. 2012). Recently, experts from the international association Food, Quality \& Health (FQH www.fqhresearch.org) have started to provide definitions for organic food (Kahl et al. 2012a), organic food quality (Kahl et al. 2012b), health (Huber et al. 2011) and organic food processing and its impact on the food (Kahl et al. 2014a, b). The FQH describes the food and production process (the production) as inseparable aspects which can be defined by criteria, indicators and measurable parameters (Kahl et al. 2012 a, b). Furthermore, they identified laboratory methods for evaluating the food (Kahl et al. 2014a, b). Reviews and primary research evaluating the quality of organic food have reduced a perspective that needs a broad evaluation to a few narrow product-related parameters (Zalecka et al. 2014). A more systematic evaluational approach is required, which also includes the perceptions of consumers.

In addition to describing the quality of organic food in itself, the concept of organic diets within organic food systems has also been investigated (Strassner et al. 2015). Organic diets could indeed comprise more than 
traditional diets with organic ingredients, such as less meat and more grain legumes, which are required to reduce the pressure on increased food production. Such discussions may contribute to change the perspective of ideal food systems from a "field to fork" approach to a "fork to field" approach, putting the stakeholders towards the end of the food chain such as wholesalers, retailers and consumers and forwards as a major driver to increase and concurrently redesign organic agriculture and food production in general.

One of the major challenges for the organic agri-food system is to change the fieldwork-driven Organic 2.0 groundwork to an Organic 3.0 methodology that uses information from a broad sector of conducted research, consumer interest and sustainable consumption as a driver of organic growth (weeding) (Kahl et al. 2010; Kahl 2012). Organic 3.0 will include information on value-added components of organic food and farming and will be supported by the rapid increase in data available to perform meta-analyses comparing levels of relevant compounds in organic and non-organic products (e.g. for plants, see Brandt et al. 2011; SmithSpangler et al. 2012; Barański et al. 2014). The results from meta-analyses indicate that the levels of some beneficial compounds such as polyphenols are significantly higher in organic crops, whereas protein levels are lower. Meta-analysis of organically produced meat and dairy products show that organic milk and meat contain significantly more beneficial omega-3 fatty acids than their conventional counterparts (e.g. Palupi et al. 2012; Średnicka-Tober et al. 2016a; Tauscher et al. 2003; Średnicka-Tober et al. 2016b). Moreover, organic milk contains more conjugated linoleic acid (CLA). Along with these nutritional advantages, pesticide residues are significantly reduced in organic crops (Lairon 2010; Smith-Spangler et al. 2012; Barański et al. 2014; Dangour et al. 2009; Smith-Spangler et al. 2012; Załęcka et al. 2014).

The Oslo Symposium in 1994 proposed a working definition of sustainable consumption as "the use of goods and services that respond to basic needs and bring a better quality of life, while minimizing the use of natural resources, toxic materials and emissions of waste and pollutants over the life cycle, so as not to jeopardize the needs of future generations"(IISD 2016).

The FAO (2012) also addresses sustainable diets, but with a slightly different definition: "Sustainable Diets are those diets with low environmental impacts which contribute to food and nutrition security and to healthy life for present and future generations. Sustainable diets are protective and respectful of biodiversity and ecosystems, culturally acceptable, accessible, economically fair and affordable, nutritionally adequate, safe and healthy, while optimizing natural and human resources". With this definition as a starting point, organic agricultre and organic diets indeed have a lot to offer for sustainable development (Strassner et al. 2015).

\section{Fostering innovative research in organic agriculture}

In summary, feeding the world must be regarded as a highly complex topic. It cannot be treated in a onedimensional manner, which is commonly the case in debates about the role of organic agriculture in food security. Longstanding solutions require that an increase in production and improvement of productivity should be accompanied by changes in lifestyles and ambitious campaigns against all forms of food waste.

Innovation is critical for all agri-food systems, including organic, and these innovations must be based on a system approach. Research should be framed by investigating solutions to reduce the yield gap between organic and conventional systems while linking sustainable consumption to sustainable production. A growing number of citizen activists have helped drive interest in research addressing the ecological challenges brought about by agriculture. These activists call for relevant research to overcome these challenges, aiming at affecting values, attitudes and politics. While engaging the public can be a key aspect of increased environmental focus, it is important not to reduce the complexity to measurable parameters when modeling and assessing the impact of the organic food system on sustainability, even if this reduction makes the outcomes easier to disseminate.

Innovations in organic agriculture can only be achieved when they are in line with the expectations of consumers (e.g. Arbenz et al. 2015). The concept and the standards of organic agriculture comprise an ethical and moral understanding of the food chain while ignoring and banning several scientific-based innovations such as GMOs, most chemical pesticides and most food processing chemicals. The organic food chain aims at minimizing risk, but is concurrently risk vulnerable because the inputs to amend possible crises are restricted. Organic agriculture needs to discuss how science can be utilized in a productive way to achieve the redesigns 
integrated in Organic 3.0, without compromising the ethics of the principles and standards.

The category of innovation is not limited to technical aspects but also relies on the creativity and diversity in perspectives of researchers, social networks and institutions. Innovation highlights the need for engagement of communities outside of those traditionally represented in environmentalism, not only so that we may investigate environmental challenges from a multitude of viewpoints but also so that the results of these investigations can be integrated into working cultures, cooperative structures and values. Therefore, it is necessary for organic farmers and the organic sector to promote a bold spirit of inclusivity in innovation and a culture of intensive learning and communication regarding new solutions and innovative practices.

In the past, organic agriculture traditions have defended deep-rooted values of rural cultures. In the future, however, traditions must be complemented by new ideas and ways of thinking as well as adapt useful modern techniques, developed in close cooperation with many engaged and competent scientists all over the world. Traditional styles of management must be called into question and evaluated with fresh perspectives. Organic 3.0 must transcend the challenges of the past to overcome classical, social and cultural frontiers in agriculture and food production. Therefore, it is critical to shift sectorial debates about morality and responsibility from a more general uptake of ethical principles to a more practical perspective examining the relationships between innovation, fairness and empowerment.

The organic food system needs increased legitimacy in our society and that happens partly by incorporating it into institutional and political innovation policies. To achieve this goal, agricultural training methods must also be reformed, and actor-friendly structures for learning scientific and non-scientific knowledge must be implemented throughout the sector.

In Organic 3.0, we need a redesign for sustainable and healthy lifestyles, not just a redesign for agroecological production methods. Thus, a critical goal for Organic 3.0 is to inform consumers and reconnect health, environment and product quality as essential elements of general human well-being as well as of the agri-food system. Research on methods to achieve the goal of healthy and sustainable organic lifestyles will need to be holistic and inter- and transdisciplinary and include affordability into food quality issues.
An increasing number of organic farmers choose not to certify their products (Veldstra et al. 2014). Organic 3.0 has to develop new standards and methods for certification to avoid overregulation while encouraging participation from farmers of multiple scales and values. This could be done by focusing on dynamic system indicators (e.g. quantifying and monitoring of wild/ endangered species on farms ) and risk-based certification procedures (Gambelli et al. 2014a, 2014b). However, finding these integral system indicators will be a challenge, and more research must be done focused on their development.

Five action areas for the development of organic agriculture over the next 30 years (1-5), and three for a longer time perspective (6-8), were recently proposed (Rahmann 2016a, b) and are in line with the contents of the present paper:

1. Conventional can learn from organic: Both conventional and organic production must increase their sustainability to be ecologically sound, maintain high ethical standards, be profitable and be social acceptable. To achieve this, we must change the industrial production chain and incorporate local farming systems, where farmers are able to make a living wage and food prices are affordable for everyone. The externalities incurred during production need to be included in the price of products.

2. Organic can learn from conventional: Organic agriculture needs to be more productive to be accepted in societies with limited land and food quantities. This means realizing that not all farm inputs are unsustainable. Clear criteria are needed on how to incorporate sustainable and healthful conventional strategies and precision farming technologies into organic practices.

3. Scale-up best organic farming practices: Best farming practices are necessary to fulfill the consumer and public demands while maintaining high efficiency when faced with limited resources. Both organic and conventional agriculture must train farming communities in best practices based on local ecological conditions and commodity types. Capacity building and training need to be supported by research, and methods to transfer best farming practices permanently across all farming systems examined.

4. Food production needs closer links to the consumers: It is important to educate consumers that, 
in a sustainable future, not everything will be readily and cheaply available. In order to preserve our environment, we must modify consumption patterns, and western countries need to reduce consumption significantly. We have to avoid food waste, reduce livestock production and utilize novel food sources. Additionally, crops need to be bred for nutrient quality rather than just high yield.

5. Farming must change from commodity production to need-based production: Non-food production must be viewed as secondary to what is needed by the local society. Additionally, local food production to support community needs must be improved and scaled up through community supported agriculture programs.

Unfortunately, there have been few discussions looking further into the future than 2050. This longterm thinking is necessary; however, because even if all five of the visions listed above come to fruition, they will not be able to fulfill the demand of 11-13 billion people. Research is needed to address the long-term sustainability, i.e. perpetuity of food systems, and must be started now. Rahmann (2016a, b) suggests three action areas to be prepared for the future beyond 2050:

6. Less livestock and changed animal husbandry systems: Numbers of livestock need to be reduced significantly. Competition for human food resources have to be minimized.

Ruminants that are able to digest fibres of non-arable land use will have an advantage in future organic food and feed systems. This will also require improved food consumption awareness about healthful diets (e.g. avoiding malnutrition with vegan diets). Invention of novel protein food resources based on insects and seafood is necessary.

7. Local vs global food chains: The transport of food must decrease significantly. Communities must be built around agricultural productive regions rather than having food produced in these regions shipped to areas where food cannot be readily grown. Additionally, people must preferentially consume locally and seasonally available food rather than relying on imports. Such a strategy must be sensibly balanced with the needs of developing regions that relay on exports. Moreover, the general use of the principle of comparative costs has to be called into question.
8. Landless food production: Organic farming currently requires improvement to healthy soil and prohibits soilless food production. However, soil is scarce, and in some areas, pollutions reduced the ability to produce healthful crops. Food can be produced on sealed surfaces (urban agriculture, indoor/household, at walls and on roofs, etc.). Additionally, aquaponics provides an opportunity to link excess nutrient production from aquatic food production with land-based food production where nutrients are limiting.

\section{Conclusion}

Organic agriculture can and should play an important role in solving future challenges in producing food. The low level of external inputs combined with knowledge on sustainablity minimizes environmental contamination and can help to produce more food for more people without negatively impacting our environment.

Organic agriculture must be supported with multidisciplinary research to find both technical and socioeconomic solutions to current agricultural-based issues. The main challenges of the future can only be overcome in a participatory approach, following an agri-food system view with enhanced sustainability, i.e. perpetuity and health as the main targets.

To scale-up organic solutions, production qualifications need to be improved. Yields per hectare can be increased in the majority of the global farming systems by improving management and implementing best practices. There is a need to transform sustainable organic food production from a system with low inputs and low outputs to one with low external inputs and medium output. Furthermore, this must be linked to local food consumption.

Organic agri-food systems must be developed to become more resilient against extreme weather conditions and climate change. Additionally, the integration of biodiversity as part of the food system must be improved. There is also a need to work on improved nutrient use efficiency and methods for controlling cycles of pests and pathogens. Innovative organic agrifood systems must determine whether and how they can achieve these objectives while supporting clean water, air and healthy soils in addition to system resilience. 
To educate people about food production, healthy diets and a sustainable lifestyle beyond food consumption is an overall need. The drivers of sustainable consumption must be identified so that they may be leveraged to encourage sustainable lifestyle adoption.

Similarly, fair distribution of high-quality food at reasonable prices is a critical issue for organic. Organic products need to become affordable to everyone in the world while keeping the standards in production high. There is a need for identifying the drivers of sustainable consumption and for contributing to enhanced sustainable lifestyles.

Organic cannot rely solely on agricultural practice improvements but must become a model for sustainable and healthy food systems both locally and globally. There is an urgent need to identify pathways towards developing these models, and with the aid of innovative organic research, the organic sector has the potential to perform pioneering work.

Acknowledgments We thank the Chungbuk Province and the Geosan County of South Korea for the financial support to make the symposium "Organic 3.0 is innovation with research" in September 2015 and as result this discussion and review paper possible.

\section{References}

Aertsens J (2011) Organic food as an emerging market: personal determinants of consumption, Supply governance and retail strategies, Ghent University. http://hdl.handle.net/1854/LU1258273. (Accessed 16 Apr. 2016).

Alexandratos N, Bruinsma J (2012) World agriculture towards 2030/2050: the 2012 revision. ESA working paper no. 12 03. Food and Agriculture Organization of the United Nations (FAO), Rome, Italy

Altieri MA (2004) Agroecology versus ecoagriculture: balancing food production and biodiversity conservation in the midst of social inequity. CEESP Occasional Papers 3:1-29

Arbenz M, Gould D and Stopes C (2015) Organic 3.0. for truly sustainable farming and consumption. Based on think tanking by SOAAN \& IFOAM - Organics International and launched at the ISOFAR International Organic EXPO 2015, Goesan County, South Korea, http://www.ifoam.bio/en/news/2016/01 /21/join-organic-30-discussion-affiliates-and-stakeholderconsultation-20152016. (Accessed 12 Apr 2016)

Auerbach R, Rundgren G, Scialabba N (2013) Organic agriculture: African experiences in resilience and sustainability. FAO, Rome, p. 210

Baker BP, Benbrook CM, Groth E, Benbrook LK (2002) Pesticide residues in conventional, integrated pest management (IPM)- grown and organic foods: insights from three US data sets. Food Addit Contam 19(5):427-446

Balfour E (1943) The living soil. Faber and Faber. UK, London

Barabanova Y, Zanoli R, Schlüter M, Stopes C (2015) Transforming food \& farming. An organic vision for Europe in 2030. IFOAM-EU, Bruxels, Belgium, 32pp

Barański M, Średnicka-Tober D, Volakakis N, Seal C, Sanderson R, Stewart GB, Benbrook C, Biavati B, Markellou E, Giotis C, Gromadzka-Ostrowska J, Rembiałkowska E, SkwarłoSońta K, Tahvonen R, Janovska D, Niggli U, Nicot P, Leifert C (2014) Higher antioxidant and lower cadmium concentrations and lower incidence of pesticide residues in organically grown crops: a systematic literature review and meta-analyses. Br J Nutr 112:794-811

Bàrberi P (2006) Special topic 4. Tillage: how bad is it in organic agriculture? In: Kristiansen P, Taji A, Collingwood RJ (eds) Organic agriculture. A global perspective. CSIRO Publishing/ CABI Publishing, (AU)/Wallingford (UK), pp. 295-303

Bàrberi $\mathrm{P}$ (2015) Functional biodiversity in organic systems: the way forward? Sustainable Agriculture Research 4:26-31

Bàrberi $\mathrm{P}$, Aendekerk R, Antichi D, Armengot L, Berner A, Bigongiali F, Blanco-Moreno JM, Carlesi S, Celette F, Chamorro L, Crowley O, Döring T, Grosse M, Haase T, Heß J, Huiting H, José-María L, Klaedtke S, Kranzler A, Luik A, Peigné J, Sukkel W, Surböck A, Talgre L and Sans FX (2014) Reduced tillage and cover crops in organic arable systems preserve weed diversity without jeopardising crop yield. In: Rahmann and Aksoy (Eds.) Proceedings 18th IFOAM Organic World Congress, Istanbul. 765-768

Bàrberi P, Burgio G, Dinelli G, Moonen AC, Otto S, Vazzana C, Zanin G (2010) Functional biodiversity in the agricultural landscape: relationships between weeds and arthropod fauna. Weed Res 50:388-401

Beijerinck MW (1901) Über oligonitrophile Mikroben. In: Centralblatt für Bakteriologie, Parasitenkunde, Infektionskrankheiten und Hygiene, Abteilung II. Band 7, 1901, 561-582

Bellarby J, Foereid B, Hastings A and Smith P (2008) Cool Farming: Climate impacts of agriculture and mitigation potential Amsterdam, Netherlands, $44 \mathrm{pp}$.

Benbrook C (2015) Embracing value-added, evidence-based diversity across the food industry is good for business. Organic Agriculture Research Symposium, February 25-26, 2015, La Crosse, Winconsin, USA, Washington State University

Bengtsson J (1998) Which species? What kind of diversity? Which ecosystem function? Some problems in studies of relations between biodiversity and ecosystem function. Appl Soil Ecol 10:191-199

Bengtsson J, Ahnstrom J, Weibull AC (2005) The effects of organic agriculture on biodiversity and abundance: a metaanalysis. J Appl Ecol 42(2):261-269

Bhattacharyya R, Ghosh B, Mishra P, Mandal B, Rao C, Sarkar D, Das K, Anil K, Lalitha M, Hati K, Franzluebbers A (2015) Soil degradation in India: challenges and potential solutions. Sustainability 7(4):3528

Bindraban PS, van der Velde M, Ye L, van den Berg M, Materechera S, Kiba DI, Tamene L, Ragnarsdóttir KV, Jongschaap R, Hoogmoed M, Hoogmoed W, Van Beek C, van Lynden G (2012) Assessing the impact of soil degradation on food production. Curr Opin Environ Sustain 4(5):478-488 
Blair A, Fritschi L, McLaughlin J, Sergi CM, Calaf GM, LeCurieux F, Baldi I, Forastière F, Kromhout H, Mannetje A (2015) Carcinogenity of tetrachlorvinphos, parathion, malathion, diazinon, and glyphosate. The Lancet Ontology 16(5):490-491. doi:10.1016/S1470-2045(15)70134-8

Blanc J (2009) Family farmers and major retail chains in the Brazilian organic sector: assessing new development pathways. J Rural Stud 25(3):322-332

Bleken MA, Steinshamn H, Hansen S (2005) High nitrogen costs of dairy production in Europe: worsened by intensification. AMBIO J Hum Environ 34(8):598-606

Bloomer D, Powrie J (eds) (2011) A guide to smart farming. Landwise Inc., Feilding, New Zealand, 188 pp

BMU/UBA (2008) Umweltbewusstsein in Deutschland 2008: Ergebnisse einer repräsentativen Bevölkerungsumfrage. Heidelberg, Hannover.

BMU/UBA (2013) Umweltbewusstsein in Deutschland 2012: Ergebnisse einer repräsentativen Bevölkerungsumfrage. Berlin, Marburg.

BMU/UBA (2015) Umweltbewusstsein in Deutschland 2014: Ergebnisse einer repräsentativen Bevölkerungsumfrage. Berlin, Dessau-Roßlau.

BÖLN (2013) Ökobarometer 2013: Repräsentative Bevölkerungsbefragung im Auftrag des Bundesministeriums für Ernährung, Landwirtschaft und Verbraucherschutz ( B M E L V ). h t t p : / / w w w . b m e 1 . de/SharedDocs/Downloads/Ernaehrung/Oekobarometer_2013. pdf,jsessionid $=$ C2EBAA3B4259054C23393B2FB16A11 AF.2_cid358?_blob = publicationFile Accessed 12 Mar 2016

Brandt K, Molgaard JP (2001) Organic agriculture: does it in hands or reduce the nutritional value of plant foods? J Sci Food Agric 81:924-931

Brandt K, Leifert C, Sanderson R, Seal CJ (2011) Agri-ecosystem management and nutritional quality of plant foods: the case of organic fruits and vegetables. Crit Rev Plant Sci 30(1-2): 177-197

Braun S, Rahmann G, Strotdrees S, Strotdrees L (2010) REvolution des Ökolandbaus !? : "Ökolandbau 3.0". Trenthorst: Thünen-Institut für ökologischen Landbau, 5 pp.

Canali S, Campanelli G, Ciaccia C, Leteo F, Testani E, Montemurro F (2013) Conservation tillage strategy based on the roller crimper technology for weed control in Mediterranean vegetable organic cropping systems. Eur J Agron 50:11-18

Canali S (2016) Italian Organic Research Strategy. Paper presented at the Italian Organic Research Conference 20th January 2016 in Rome

Chathoth P, Altinay L, Harrington RJ, Okumus F, Chan ESW (2013) Co-production versus co-creation: a process based continuum in the hotel service context. Int J Hosp Manag 32:1-11

Clergue B, Amiaud B, Pervanchon F, Lasserre-Joulin F, Plantureux S (2005) Biodiversity: function and assessment in agricultural areas - a review. Agron Sustain Dev 25:1-15

Cooper JM, Baranski M, Nobel de Lange M, Bàrberi P, Fliessbach A, Peigné J, Berner A, Brock C, Casagrande M, Crowley O, David C, De Vliegher A, Döring T, Entz M, Grosse M, Haase T, Halde C, Hammerl V, Huiting H, Leithold G, Messmer M, Schloter M, Sukkel W, Van der Heijden M, Willekens K, Wittwer R and Mäder P (2014) Effects of reduced tillage in organic farming on yield, weeds and soil carbon: metaanalysis results from the TILMAN-ORG project. In:
Rahmann and Aksoy (Eds.) Proceedings 18th IFOAM Organic World Congress, Istanbul. 1163-1166

Costanzo A, Bàrberi P (2014) Functional agri-biodiversity and agri-ecosystem services in sustainable wheat production. A review. Agron Sustain Dev 34:327-348

Crews TE, Peoples MB (2004) Legume versus fertilizer sources of nitrogen: ecological tradeoffs and human needs. Agric Ecosyst Environ 102:279-297

Dangour AD, Dodhia SK, Hayter A, Allen E, Lock K, Uauy R (2009) Nutritional quality of organic foods: a systematic review. Am J Clin Nutr. doi:10.3945/ajen.2009.28041

Daniel-Gromke J, Liebetrau J, Nenysenko V, Krebs C (2015) Digestion of bio-waste - GHG emissions and mitigation potential. Energy, sustainability and Society 5(3):1-12

de Ponti T, Rijk B, van Ittersum MK (2012) The crop yield gap between organic and conventional agriculture. Agric Syst 108:1-9

Deininger K, Byerlee D, Lindsay J, Norton A, Selod H, Stickler M (2011) Rising global interest in farmland. Can it yield sustainable and equitable benefits? The World Bank, Washington, D.C, p. 266

DeLong C, Cruse R, Wiener J (2015) The soil degradation paradox: compromising our resources when we need them the most. Sustainability 7(1):866-879

Deryng D, Conway D, Ramankutty N, Price J, Warren R (2014) Global crop yield response to extreme heat stress under multiple climate change futures. Environ Res Lett 9(3): 13pp. doi:10.1088/1748-9326/9/3/034011

Diacono M, Fiore A, Farina R, Canali S, di Bene D, Testani E, Montemurro F (2016) Combined agri-ecological strategies for adaptation of organic horticultural systems to climate change in Mediterranean environment. Ital J Agron 11:85-91

Draghetti A (1948) Principi di fisiologia dell'azienda agraria Milano/Bologna: Istituto editoriale agricolo, Italy, $355 \mathrm{pp}$

Dregne HE (ed) (1992) Degradation and restoration of arid lands. Texas Technical University, Lubbock TX, USA, 289pp

EC (2007) Council Regulation (EC) No 834/2007on organic production and labelling of organic products and repealing Regulation (EEC) No 2092/91. Off J Eur Union L189:1-23

Erisman JW, Galloway JN, Seitzinger S, Bleeker A, Dise NB, Petrescu AMR, Leach AM, de Vries W (2013) Consequences of human modification of the global nitrogen cycle. Philosophical Transactions of the Royal Society of London B: Biological Sciences 368(1621)

Erisman JW, Sutton MA, Galloway J, Klimont Z, Winiwarter W (2008) How a century of ammonia synthesis changed the world. Nature Geosci 1(10):636-639

Erisman JW, Van Eekeren N, Koopmans C, De Wit J, Cuijpers W, Oerlemans N, and Koks B (2016) Agriculture and biodiversity: a better balance benefits both. AIMS Agriculture and Food.

European-Commission (2012) European Commission. Prospects for agricultural markets and income in the EU 2012-2022. Directorate-General for Agriculture and Rural Development (December).

European Commission (EC) (2016) EGTOP Final Report on Organic Fertilizers and Soil Conditioners (II). http://ec. e u ropa.e u/a griculture/organ i c/e u policy/expertadvice/documents/final-reports/final-reportegtop-onfertilizers-2_en.pdf. Accessed 10 March 2016)

Ezzati $\mathrm{M}$ et al (2016) Trends in adult body-mass index in 200 countries from 1975 to 2014: a pooled analysis of 1698 
population-based measurement studies with $19 \cdot 2$ million participants. Lancet 387:1377-1396

FAO (2011a) Evaluation of certain veterinary drug residues in food [Homepage of WHO Technical Report Series], [Online]. Available: http://whqlibdoc.who. int/publications/2012/9789241209694_eng.pdf. Accessed on 16 Apr 2016.

FAO (2011b) The state of the world's land and water resources for food and agriculture (SOLAW)-managing systems at risk. NY, UK, Earthscan, New York

FAO (2012) Statistical Yearbook. Part1 The Setting. Rome, Food and Agricultural Organisation of the United Nations.

FAO (2013) Food wastage footprint-impacts on natural resources. Rome, pp 63

FAO (2015a) Natural capital impacts in agriculture. Supporting better business decision-making.www.fao. org/fileadmin/templates/nr/sustainability_ pathways/docs/Natural_Capital_Impacts in_Agriculture final.pdf. Accessed on $\overline{16}$ Apr $20 \overline{16}$.

FAO, IFAD and WFP (2014) The State of Food Insecurity in the World 2014. Strengthening the enabling environment for food security and nutrition. Rome, FAO

FAO/WHO (1999) Codex Alimentarius Commission approves guidelines for organic food. (http://www.un. org/press/en/1999/19990706.SAG44.html, download 19.5.16)

FAOSTAT (2013) FAOSTAT database. Food and Agriculture Organization of the United Nations. Available at: http://faostat.fao.org Accessed on 16Apr 2016.

Felber C (2015) Change everything - creating an economy for the economy of common good. Zed books, London, 192pp

Fiala N (2008) Meeting the demand: an estimation of potential future greenhouse gas emissions from meat production. Ecol Econ 67(3):412-419

Fiala N (2009) The greenhouse hamburger. Sci Am 300:72-75

Frøseth RB 2016. Nitrogen dynamics in an organic green manure - cereal rotation and mineralization of clover leaves at low temperature. Norwegian University of Life Sciences. Philosophiae Doctor (PhD) Thesis 2016:25, ISSN: 18946402, ISBN: 978-82-575-1335-1.

Gabriel D, Sait SM, Kunin WE, Benton TG (2013) Food production vs. biodiversity: comparing organic and conventional agriculture. J Appl Ecol 50(2):355-364

Gambelli D, Solfanelli F, Zanoli R, Zorn A, Lippert C, Dabbert S (2014a) Non-compliance in organic farming: a cross-country comparison of Italy and Germany. Food Policy 49(P2):449-458

Gambelli D, Solfanelli F, Zanoli R (2014b) Feasibility of riskbased inspections in organic farming: results from a probabilistic model. Agricultural Economics (United Kingdom) 45(3):267-277

Gattinger A, Muller A, Haeni M, Skinner C, Fliessbach A, Buchmann N, Mäder P, Stolze M, Smith P, Scialabba NEH, Niggli U (2012) Enhanced top soil carbon stocks under organic farming. Proc Natl Acad Sci 109(44):18226-18231

Gerber PJ, Steinfeld H, Henderson B, Mottet A, Opio C, Dijkman J, Falcucci A, Tempio G (2013) Tackling climate change through livestock - a global assessment of emissions and mitigation opportunities. Food and Agriculture Organization of the United Nations (FAO), Rome

Golan E, Kuchler F, Mitchell L (2001) Economics of food labeling. J Consum Policy 24(2):117-184
Gosling P, Shepherd M (2005) Long-term changes in soil fertility in organic arable farming systems in England, with particular reference to phosphorus and potassium. Agric Ecosyst Environ 105:425-432

Grebmer KV, Saltzman A, Birol E, Wiesmann D, Prasai N, Yin S, Yohannes Y, Menon P, Thompson J and Sonntag A (2014) Global hunger index. The challenge of hidden hunger. Bonn / Washington, D.C. / Dublin, Welthungerhilfe / IFPRI / Concern worldwide $56 \mathrm{pp}$.

Grinsven HJMV, Erisman JW, Wd V, Westhoek H (2015) Potential of extensification of European agriculture for a more sustainable food system, focusing on nitrogen. Environ Res Lett 10(2):025002

Grönroos C (2011) Value co-creation in service logic: a critical analysis. Mark Theory 11(3):279-301

Gurr GM, Wratten SD, Luna JM (2003) Multi-function agricultural biodiversity: pest management and other benefits. Basic and Applied Ecology 4:107-116

Gustavsson J, Cederberg C, Sonesson U, van Otterdijk R and Meybeck A (2011) Global food losses and food waste- extent, causes and prevention. Rome. http://foodsecurityindex. eiu.com/Home/DownloadResource?fileName=EIU GFSI\%202014_Special\%20report_Food\%201oss.pdf. (Accessed 16 Apr 2016)

Haas G, Deittert C, Köpke U (2007) Farm-gate nutrient balance assessment of organic dairy farms at different intensity levels in Germany. Renew Agr Food Syst 22:223-232

Hamm U, Häring A, Horn S, Hülsbergen HJ, Isermeyer F, Lange S, Michaelis T, Niggli U, Rahmann G (eds) (2016) Future strategy of the organic food and farming sector. A result of a particpatory approach with the stakeholders 2014-2016. Prepared for the Fachforum Ökologische Lebensmitttelwirtschaft of the German Agricultural Research Alliance, Braunschweig, Germany, 19 pp.

Harvey D, Hubbard C (2013) Reconsidering the political economy of farm animal welfare: an anatomy of market failure. Food Policy 38:105-114

Hauser R, Skakkebaek NE, Hass U, Toppari T, Juul A, Andersso AM, Kortenkamp A, Heindel JJ, Trasande L (2015) Male reproductive disorders, diseases and costs of exposure to endocrine-disrupting chemicals in the European Union. J Clin Endocrinol Metab 100(4):1267-1277

Hellriegel $\mathrm{H}$ and Wilfarth $\mathrm{H}$ (1888) Untersuchungen über die Stickstoffnahrung der Gramineen und Leguminosen. Beilageheft zu der Zeitschrift des Vereins der RübenzuckerIndustrie des Deutschen Reichs Bd. 38, Berlin, Germany.

Hemmerling S, Hamm U, Spiller A (2015) Consumption behaviour regarding organic food from a marketing perspective - a literature review. Org Agric 5(4):277-313

Henchion M, McCarthy M, Resconi VC, Troy D (2014) Meat consumption: trends and quality matters. Meat Sci 98(3):561-568

Hess J, Rahmann G (eds) (2005) Beiträge zur 8. Wissenschaftstagung Ökologischer Landbau "Ende der Nische" Kassel, 1.-4. März 2005. Kassel Univ Pr, Germany, Kassel, 656pp

Hine R, Pretty J and Twarog S (2008) Organic agriculture and food security in Africa. Geneva and New York, (UNCTAD/DITC/ TED/2007/15). United Nations. http://unctad. org/en/docs/ditcted200715_en.pdf 
Hjelmar U (2011) Consumers' purchase of organic food products. A matter of convenience and reflexive practices. Appetite 56: 336-344

Hole DG, Perkins AJ, Wilson JD, Alexander IH, Grice PV, Evans $\mathrm{AD}$ (2005) Does organic farming benefit biodiversity? Biol Conserv 122(1):113-130

Holt-Giménez E, Shattuck A, Altieri M, Herren H, Gliessman S (2012) We already grow enough food for 10 billion people... and still can't end hunger. J Sustain Agric 36(6):595-598

Hov Ø, Cubasch U, Fischer E, Höppe P, Iversen T, Kvamstø NG, Kundzewicz ZW, Rezacova D, Rios D, Santos FD et al. 2013. Extreme weather events in Europe: preparing for climate change adaptation [Internet]. Oslo: Norwegian Meteorological Institute; [cited 2013 Nov 20]. Available from: http://www.dnva.no.

Howard P (2013) Organic industry structure. Journal of the New Media Caucus 5(3)

Huber M, Knottnerus JA, Green L, Horst HvD, Jadad AR, Kromhout D, Leonard B, Lorig K, Loureiro MI, von en Meer JWM, Schnabel P, Smith R, Weel Cv and Smid H (2011) How should we define health? BMJ 343.

Huesmann MH (2001) Can pollution problems be effectively solved by environmental science and technology? An analysis of critical limitations. Ecol Econ 37:271-287

Hughner RS, McDonagh P, Prothero A, Shultz CJ, Stanton J (2007) Who are organic food consumers? A compilation and review of why people purchase organic food. J Consum Behav 6(2-3):94-110

Hülsbergen, KJ, Rahmann, G (eds) (2013) Klimawirkungen und Nachhaltigkeit ökologischer und konventioneller Betriebssysteme - Untersuchungen in einem Netzwerk von Pilotbetrieben. Braunschweig: Johann Heinrich von ThünenInstitut, 412 p, Thünen Rep 8, DOI: 10.3220/REP_8_2013

IAASTD (2009) Agriculture at a crossroads. Island Press, Washington, D.C

IFOAM (2005) Principles of organic agriculture. Bonn, Germany

IISD (2016) The imperative of sustainable production and consumption. International Institute for Sustainable Development (IISD) Reporting Services: http://www.iisd. ca/consume/oslo004.html

IPCC (2014a) Climate Change 2014: Mitigation of Climate Change. Contribution of Working Group III to the Fifth Assessment Report of the Intergovernmental Panel on Climate Change. Cambridge, United Kingdom and New York, NY, USA, Cambridge University Press.

IPCC (2014b) Climate Change 2014: Synthesis Report. Contribution of Working Groups I, II and III to the Fifth Assessment Report of the Intergovernmental Panel on Climate Change [Core Writing Team, R.K. Pachauri and L.A. Meyer (eds.)]. Geneva, Switzerland, IPCC.

Jahn G, Schramm M, Spiller A (2005) The reliability of certification: quality labels as a consumer policy tool. J Consum Policy 28(1):53-73

Johannsson L, Haglund A, Berglund L, Lea P, Risvik E (1999) Preference for tomatoes, affected by sensory attributes and information about growth conditions. Food Qual Prefer 10(4-5):289-298

Jonas H (1984) The imperative of responsibility: in search of an ethics for the technological age, University of Chicago Press, 263 pp.
Jonston AE, Poulton PR, Coleman K (2009) Soil organic matter: its importance in sustainable agriculture and carbon dioxide fluxes. Adv Agron 101:1-57

Kahl J (2012) Organic food quality: from field to fork. J Sci Food Agric 92(14):2751-2752

Kahl J, Alborzi F, Beck A, Bugel S, Busscher N, Geier U, Matt D, Meischner T, Paoletti F, Pehme S, Ploeger A, Rembiałkowska E, Schmid O, Strassner C, Taupier-Letage B, Załęcka A (2014a) Organic food processing: a framework for concept, starting definitions and evaluation. J Sci Food Agric 94(13):2582-2594

Kahl J, Baars T, Bügel S, Busscher N, Huber V, Kusche D, Rembiałkowska E, Schmid O, Seidel K, Taupier-Letage B, Velimirov A, Załęcka A (2012b) Organic food quality: a framework for concept, definition and evaluation from the European perspective. J Sci Food Agric 92(14):2760-2765

Kahl J, van der Burgt GJ, Kusche D, Bugel S, Busscher N, Hallmann E, Kretzschmar U, Ploeger A, Rembiałkowska E, Huber M (2010) Organic food claims in Europe. Food Technol 64(3):38-46

Kahl J, Załęcka A, Ploeger A, Bügel S, Huber M (2012a) Functional food and organic food are competing rather than supporting concepts in Europe. Agriculture 2(4):316

Kahl J, Bodroza-Solarov M, Busscher N, Hajslova J, Kneifel W, Kokornaczyk MO, van Ruth S, Schulzova V, Stolz P (2014b) Status quo and future research challenges on organic food quality determination with focus on laboratory methods. J Sci Food Agric 94(13):2595-2599

Kesse-Guyot E, Péneau S, Méjean C, Szabo de Edelenyi F, Galan P, Hercberg S, Lairon D (2013) Profiles of organic food consumers in a large sample of French adults: results from the Nutrinet-Santé cohort study. PLoS One 8(10)

Koepf HH, Pettersson BD, Schaumann W (1976) Bio-dynamic agriculture. Anthroposophic Press, Hudson, NY

Köpke U (2005) Organic foods: do they have a role? Elmadfa I (ed.): Diet diversification and health promotion. Forum of Nutrition, Basel. Karger, 2005, vol 57, 62-72

Köpke U (2016a) Konzept Modellbetrieb Wiesengut Multifunktionale Landwirtschaft durch Organischen Landbau. Call date: 5 April 2016. https://www.wiesengut. uni-bonn.de/betrieb/konzept-modellbetrieb-wiesengut.

Köpke U (2016b) Entwicklung des Ökologischen Landbaus - zum Wechselspiel zwischen Landwirtschaft, Naturschutz und Ökologie (the evolution of organic agriculture — on the interplay between farming, conservation and ecology). Natur und Landschaft 91(9/10):445-449

Köpke U (2017) Ressourcenschutz und Ökologische Leistungen. B Freyer (ed.) Ökologischer Landbau - Grundlagen, Wissensstand und Herausforderungen. UTB - Agrarwissenschaften, Stuttgart, ISBN 9 783825246396, 590-612.

Kristiansen P, Taji A and Reganold J (eds) (2006) Organic agriculture. A global perspective. Collingwood, Victoria, Australia, 484 pp.

Kriwy P, Mecking R-A (2012) Health and environmental consciousness, costs of behaviour and the purchase of organic food. Int J Consum Stud 36(1):30-37

Kumar N, Dushenkov V, Motto H, Raskin I (1995) Phytoextraction: the use of plants to remove heavy metals from soils. Environ Sci Technol 29(5):1232-1238

Kummu M, Hd M, Porkka M, Siebert S, Varis O, Ward PJ (2012) Lost food, wasted resources: global food supply chain losses 
and their impacts on freshwater, cropland and fertiliser use. Sci Total Environ 438:477-489

Kuosmanen T, Niemi J (2009) What explains the widening gap between the retail and producer prices of food? Agricultural and Food Science 18:317

Laird TJ (1995) Community supported agriculture: a study of an emerging agricultural alternative. In Partial Fulfilment of the Requirements for the Degree of Master of Science Specializing in Natural Resource Planning.The Faculty of the Graduate Collage of The University of Vermont, $128 \mathrm{pp}$

Lairon D (2010) Nutritional quality and safety of organic food. A review. Agronomy for Sustainable Development 30(1):33-41

Lal R (2009) Soils and food sufficiency. A review. Agron Sustain Dev 29(1):113-133

Lennard WA, Leonard BV (2006) A comparison of three different hydroponic sub-systems (gravel bed, floating and nutrient film technique) in an aquaponic test system. Aquac Int 14(6):539-550

Levidow L, Birch K, Papaioannou T (2012) Divergent paradigms of European agri-food innovation: the Knowledge-Based Bio-Economy (KBBE) as an R\&D agenda. Sci Technol Hum Values 38:94-125

Løes, AK 2016. What does the organic sector think about different phosphorous fertilizers? NORSØK report Vol. 1/No. $3 /$ 2016. Norwegian Centre for Organic Agriculture (NORSØK), Tingvoll, Norway.

Løes AK, Bünemann EK, Cooper J, Hörtenhuber S, Magid J, Oberson A, Möller K (2016) Nutrient supply to organic agriculture as governed by EU regulations and standards in six European countries. Org Agr. doi:10.1007/s13165-016-0165-3

Lotter DW (2003) Organic agriculture. J Sustain Agric 21(4):59-128

Mäder P, Fliessbach A, Dubois D, Gunst L, Fried P, Niggli U (2002) Soil fertility and biodiversity in organic farming. Science 296:1694-1697

Mazzoncini M, Canali S, Giovannetti M, Castagnoli M, Tittarelli F, Antichi D, Nannelli R, Cristani C, Bàrberi P (2010) Comparison of organic and conventional stockless arable systems: a multidisciplinary approach to soil quality evaluation. Appl Soil Ecol 44:124-132

Migliorini P, Moschini V, Tittarelli F, Ciaccia C, Benedettelli S, Vazzana C, Canali S (2014) Agronomic performance, carbon storage and nitrogen utilisation of long-term organic and conventional stockless arable systems in Mediterranean area. Eur J Agron 52:138-145

McDonough M, Braungart M (2002) Cradle to cradle : remaking the way we make things. North Point Press, New York

Mijatovic D, Van Oudenhoven F, Eyzaguirre P, Hodgkins T (2013b) The role of agricultural biodiversity in strengthening resilience to climate change: towards an analytical framework. Int J Agric Sustain 11(2):95-107

Mijatovic D, Eyzaguirre P, Milder J (2013a) Landscape perspectives on in situ/on farm crop conservation. Report to the landscapes for people, food and nature intiative. Maccarese: Bioversity International, Rome, p. 66

Millennium Ecosystem Assessment (2005) Ecosystems and human well-being: biodiversity synthesis. World Resources Institute, Washington DC

Ministry of Agriculture Fisheries and Food of the United Kingdom (2000) Energy use in organic farming systems. MAFF Project Code OF0182. London, UK.
Mollison BC, Holmgren D (1978) Permaculture One: a perennial agriculture for human settlements. Transworld, Melbourne

Mollison BC (1990) Permaculture: a practical guide for a sustainable future. Island Press

Montgomery D (2007) Soil erosion and agricultural sustainability. Proc Natl Acad Sci U S A 104(33):13268-13272

Moonen AC, Bàrberi P (2008) Functional biodiversity: an agriecosystem approach. Agric Ecosyst Environ 127:7-21

Moos JH, Schrader S, Paulsen HM, Rahmann G (2016) Occasional reduced tillage in organic farming can promote earthworm performance and resource efficiency. Appl Soil Ecol 103:22-30

Mozafar A (1993) Nitrogen fertilisers and the amount of vitamins and plants: a review. J Plant Nutrition 16(12):2479-2506

Mpountoukas P, Pantazaki A, Kostareli E, Christodoulou P, Kareli D, Polilou S, Mourelatos C, Lambropoulou V, Lialiaris T (2010) Cytogenetic evaluation and DNA interaction studies on the food colorants amaranth, erythrosine and tartrazine. Food Chemistry Toxicol 48(10):2934-2944

Müller C (Ed.) (2011) Urban Gardening. Über die Rückkehr der Gärten in die Stadt. Oekom-Verlag, 210 pp

Müller-Lindenlauf M (2009) Umweltwirkungen ökologisch wirtschaftender Milchviehbetriebe unterschiedlicher Fütterungsintensität und Produktionsstruktur. $\mathrm{PhD}$ thesis, University of Bonn. Berlin, Germany, Dr. Köster.

Naspetti S, Zanoli R (2009) Organic food quality and safety perception throughout Europe. J Food Prod Mark 15(3):249-266

Naspetti S, Zanoli R (2014) Organic consumption as a change of mind? Exploring consumer narratives using a structural cognitive approach. Journal of International Food \& Agribusiness Marketing 26(4):258-285

$\mathrm{Ng} \mathrm{M}$ et al (2014) Global, regional, and national prevalence of overweight and obesity in children and adults during 19802013: a systematic analysis for the Global Burden of Disease Study 2013. Lancet 384(9945):766-781

Nida Rümelin J (2005) Angewandte Ethik. Die Bereichsethiken und ihre theoretische Fun- dierung. Stuttgart. 2. Edition.

Niggli U (2016) "CRISPR hat großes Potenzial”. Interview in the German newspaper "taz" (Die Tageszeitung) from 6.4.2016 (http://www.taz.de/!5290509/)

Niggli U (2014) Sustainability of organic food production: challenges and innovations. Proc Nutr Soc 74(01):83-88

Niggli U, Rahmann G (2013) Forschung - Treibende Kraft für Veränderungen. Ökologie \& Landbau 167(3):12-14

Niggli U, Baker BP, Rahmann G, Cuoco E, Möller C, Ssebunya B, Shaikh Tanveer H, Wivstad M, Chang J, Soto G, Gould D, Lampkin N, Chander M, Soto G, Gould D, Lampkin N, Chander M, Mapusua K, Wynen E, Qiao Y (2014) Technology Innovation Platform of IFOAM (TIPI): a global vision and strategy for organic farming research, first draft, October 12, 2014, first draft, presented at the TIPI workshop. Frick: FiBL, 78 pp.

Niggli U, Fließbach A, Hepperly P and Scialabba N (2009) Low greenhouse gas agriculture: mitigation and adaptation potential of sustainable farming systems. FAO, April 2009, Rev. 2 - 2009.

Niggli U, Plagge J, Reese S, Fertl T, Schmid O, Brändli U, Bärtschi D, Pöpsel G, Hermanowski R, Hohenester H and Grabmann G (2015) Mit Bio zu einer modernen nachhaltigen Landwirtschaft. Ein Diskussionsbeitrag zum Öko- oder Biolandbau 3.0. 2nd draft. Prepared for the German speaking Organic Associations of Bioland e.V. (Mainz, Germany), 
BioAustria, (Vienna, Austria) and BioSuisse (Basel, Switzerland), $36 \mathrm{pp}$.

Noleppa J (2016). Pflanzenschutz in Deutschland und Biodiversität. Auswirkungen von Pflanzenschutzstrategien der konventionellen und ökologischen Landbewirtschaftung auf die regionale und globale Artenvielfalt. HFFA Research $\mathrm{GmbH}$, Band 1/2016, www.hffa-research.com, 60 pp.

Nuutila J, Kurppa S (2016a) The Finnish organic food chain - an activity theory approach. Organic Agricultre 6(1):49-56

Nuutila J, Kurppa S (2016b) Reaching goals for organic food in Finland - which changes should occur in the food chain? Org Agric. doi:10.1007/s13165-016-0158-2

Pugesgaard S, Olesen JE, Jørgensen U, Dahlgaard T (2014) Biogas in organic agriculture-effects on productivity, energy self-sufficiency and greenhouse gas emissions. Renewable Agriculture and Food Systems 29(1):28-41

OECD (2014) Overview of the OECD-FAO Outlook 2014-2023. OECD Publishing, Paris

OECD and FAO (2015) OECD and FAO Agricultural Outlook 2015-2024. OECD Publishing, Paris, 144pp

OECD-FAO (2013) Agricultural Outlook 2012-2021. Rome

Oeld-Wieser T and Darnhofer I (2009) Gender Issues in der Landwirtschaft. Jahrbuch der Österreichischen Gesellschaft für Agrarökonomie 18 (2), Wien

Oppermann R and Rahmann G (2009) Neue Aufgaben der Vertrauensbildung in der Ökologischen Landwirtschaft. Applied Agriculture and Forestry Reserach special edition 314, 77-98, Braunschweig

Oppermann R, Rahmann G and Schumacher U (2009) Wo steht der Ökologische Landbau heute mit Blick auf zentrale Forderungen der Tierschützer und den tierethischen Diskurs in unserer Gesellschaft? Applied Agriculture and Forestry Research special edition 314, 7-20, Braunschweig

Padel S, Foster C (2005) Exploring the gap between attitudes and behavior: understanding why consumers buy or do not buy organic food. Br Food J 107(8):606-625

Palupi E, Jayanegara A, Ploeger A, Kahl J (2012) Comparison of nutritional quality between conventional and organic dairy products: a meta-analysis. J Sci Food Agric 92(14):2774-2781

Paull J (2011) Koberwitz (Kobierzyce): In the footsteps of Rudolf Steiner. http://orgprints.org/18836/1/Paul12011 KoberwitzJOS.pdf. (Accessed 16 Apr. 2016)

Paulsen HM, Haneklaus S, Rahmann G, Schnug E (2009a) Organic plant production-limited by nutrient supply?: an overview. In: Proceedings CIEC 2009: 18th Symposium of the International Scientific Centre of Fertilizers, more sustainability in agriculture: new fertilizers and fertilization management, 8-12 November 2009 Rome, Italy. Rome: CIEC, 373-380

Paulsen HM, Schrader S, Schnug E (2009b) Eine kritische Analyse von Ruschs Theorien zur Bodenfruchtbarkeit als Grundlage für die Bodenbewirtschaftung im Ökologischen Landbau. Landbauforschung - vTI Agriculture and Forestry Research 59(3):253-268

Paulsen MP, Köpke U, Oberson A, Rahmann G (2016) Phosphorus - the predicament of organic farming. In: Ewald Schnug E, de Kok LJ (eds) Phosphorus in agriculture: 100\% zero. Springer, Dordrecht, The Netherlands, pp. 195-214

Pearce D and Moran D (1994) The economic value of biodiversity. London, UK, IUCN - The World Conservation Union, Earthscan Publications Ltd, 172 pp.
Pearson D, Henryks J, Moffitt E (2007) What do buyers really want when they purchase organic foods? An investigation using product attributes. Journal of Organic Systems 2(1):1-9

Pearson D, Henryks Jand Jones H (2011) Organic food: what we know (and do not know) about consumers. Renewable Agriculture and Food Systems 26(02):171-177

Peigné J, Ball BC, Roger-Estrade J, David C (2007) Is conservation tillage suitable for organic farming? Soil Use Manag 23:129-144

Peigné J, Casagrande M, Payet V, David C, Sans FX, BlancoMoreno JM, Cooper J, Gascoyne K, Antichi D, Bàrberi P, Bigongiali F, Surböck A, Kranzler A, Beeckman A, Willekens K, Luik A, Matt D, Grosse M, Heß J, Clerc M, Dierauer H, Mäder P (2016) How organic farmers practice conservation agriculture in Europe. Renewable Agriculture and Food Systems 31(1):72-85

Pimentel D (2006) Soil erosion: a food and environmental threat. Environ Dev Sustain 8:119-137

Pino G, Peluso AM, Guido G (2012) Determinants of regular and occasional consumers' intentions to buy organic food. J Consum Aff 46(1): 157-169

Ponisio LC, M'Gonigle LK, Mace KC, Palomino J, de Valpine P, Kremen C (2015) Diversification practices reduce organic to conventional yield gap. Proc R Soc B 282:20141396. doi:10.1098/rspb.2014.1396 (Accessed 16 Apr 2016)

Pretty J, Hine R (2001) Reducing food poverty with sustainable agriculture: a summary of new evidence. Final report from the 'SAFE World' Research Project. University of Essex, Colchester, UK, 136pp

Price L, de la Rue du Can S, Sinton J, Worrell E, Nan Z, Sathaye J, Levine M (2006) Sectoral trends in global energy use and greenhouse gas emissions. Berkeley, Ernest Orlando Lawrence Berkeley National Laboratory 3(2):263-319

Quinn S (2016) Number of vegans in Britain rises by $360 \%$ in 10 years. The Telegraph 18:2016

Rabalais NN, Turner RE, Diaz RJ, Justic D (2009) Global change and eutrophication of coastal waters. ICES J Mar Sci 66(7): $1528-1537$

Rahmann G (2000) Biotoppflege als neue Funktion und Leistung der Tierhaltung. Agraria 24:365

Rahmann G (2010) Impact of organic farming on global warming - recent scientific knowledge. In: Book of Proceedings/International Conference on Organic Agriculture in Scope of Environmental Problems: 03-07 February 2010, Famagusta, Cyprus Island. Famagusta: European Mediterranean Conferences Conventions, 1-7

Rahmann G (2011) Biodiversity and organic farming: what do we know? Landbauforsch 61(3):189-208

Rahmann G (2016b) Ecological organic agriculture knowledge, information and experiences: going from Organic 1.0 towards Organic 3.0. In: Loconto AM, AdeOluwa OO, Akinbamijo Y (eds) Achieving social and economic development in Africa through ecological and organic agricultural alternatives. Food and Agriculture Organization of the United Nations, Abuja, Nigeria, pp. 82-90

Rahmann, G (2015) Organic 3.0 needs significant and brave innovations with research. Discussion paper presented at the ISOFAR symposium, Organic 3.0 is Innovation with Research on the opening session on the 20th September 2015 in the LOHAS academy in Goesan. South Korea, 3 pp.

Rahmann G, Aksoy U (eds) (2014) Building Organic Bridges : Vol. 2, Germany - India ; Proceedings of the 4th ISOFAR Scientific 
Conference at the Organic World Congress 2014, 13-15 October 2014 in Istanbul, Turkey. Braunschweig: Johann Heinrich von Thünen-Institut, 404 p, Thünen Rep 20, Vol. 2

Rahmann G, Aulrich K, Barth K, Böhm H, Koopmann R, Oppermann R, Paulsen HM, Weißmann F (2008) Klimarelevanz des ökologischen Landbaus: Stand des Wissens. Landbauforsch 58(1-2):71-89

Rahmann G, Godinho D (eds) (2012) Tackling the future challenges of organic animal husbandry. Braunschweig: vTI, Landbauforsch SH 362:481pp

Rahmann G, Köpke U (2013) Ökoforschung international: globale Vernetzung immer wichtiger. Ökol Landbau (167,3):26-28

Rahmann G, Oppermann R, Paulsen HM, Weißmann F (2009) Good, but not good enough?: research and development needs in organic farming. Landbauforsch 59(1):29-40

Rahmann G, Strotdrees S, Strotdrees L, Braun S (2013) Gesucht: Ökolandbau 3.0: Der Ökolandbau muss sich weiter entwickeln. Lebendige Erde 14(5):16-17

Rahmann G (2016a) Ecological organic agriculture knowledge, information and experiences: going from Organic 1.0 towards Organic 3.0. In: Loconto A, AdeOluwa O, Akinbamijo Y (eds) Achieving social and economic development in Africa through ecological and organic agricultural alternatives. FAO Series, Rome, pp. 21-30

Raviv M (2010) Is organic horticulture sustainable? Chronica Horticulturae 50:7-14

Reganold JP, Wachter JM (2016) Organic agriculture in the twenty-first century. Nature Plants . doi:10.1038 /NPLANTS.2015.221Vol. 2

Reissig L, Kohler A, Rossier R (2015) Workload on organic and conventional family farms in Switzerland. Organic Agriculture, online first 17.9.2015, pp 1-18

Rob Hopkins R (2008) The transition handbook: from oil dependency to local resilience. Green Books, Totnes, Devon, 82 pp

Rockström J et al (2009) A safe operating space for humanity. Nature, Feature 461:472-475

Rodhe LKK, Ascue J, Willén A, Vererfors Persson B, Nordberg Å (2015) Greenhouse gas emissions from stirage and field application of anaerobically digested and non-digested cattle slurry. Agric Ecosyst Environ 199:358-368

Rosegrant M, Paiser M, Meijer S and Witcover J (2001) Global food projections to 2020. 2020 vision series, International Food Policy Research Institute 54 pp.

Rosenberger E, Götz K-U, Dodenhoff J, D. Krogmeier, R. Emmerling, B. Luntz and H. Anzenberger (2004) Überprüfung der Zuchtstrategie beim Fleckvieh, Bayerische Landesanstalt für Landwirtschaft Institut für Tierzucht. Poing/Grub, Germany

Rützler H and Reiter W (2014) Organic 3.0-Trend- und Potenzialanalyse für die Biozukunft. Prepared for Biofach 2014 by Zukunftsinstitut Austria, Vienna, Austria, 64 pp.

Sanchez PA, Swaminathan MS (2005) Hunger in Africa: the link between unhealthy people and unhealthy soil. Lancet 265 : $442-444$

Savory A, Butterfield J (1999) Holistic management-a new framework for decision making. Island Press, Washington DC, USA, 616p

Scherr SJ, McNeely JA (2008) Biodiversity conservation and agricultural sustainability: towards new paradigm of 'ecoagriculture' landscapes. Philos Trans R Soc Lond Ser B Biol Sci 363(1491):477-494
Scialabba NE-H, Müller-Lindenlauf M (2010) Organic agriculture and climate change. Renewable Agriculture and Food Systems 25(2):158-169

Seitzinger SP, Kroeze C, Bouwman AF, Caraco N, Dentener F, Styles RV (2002) Global patterns of dissolved inorganic and particulate nitrogen inputs to coastal systems: recent conditions and future projections. Estuaries 25:640-655

Seufert V, Ramankutty N, Foley JA (2012) Comparing the yields of organic and conventional agriculture. Nature 485(7397): 229-232

Siegmeier T, Blumenstein B, Möller D (2014a) The alliance of agricultural bioenergy and organic farming topics in scientific literature. Org Agric 2014(4):243-268

Siegmeier T, Blumenstein B, Mühlrath D and Möller D (2014b) Structure and development of scientific journal publications on organic agriculture: a scientometric review. 4th ISOFAR Scientific Conference. 'Building Bridges', at the Organic World Congress 2014. G. Rahmann and U. Aksoy. Istanbul, Turkey. http://orgprints.org/22776/1/22776OWC2014_MM.pdf (Accessed 16 Apr 2016).

Smith-Spangler C, Brandeau ML, Hunter GE, Bavinger JC, Pearson M, Eschbach PJ, Sundaram V, Liu H, Schirmer P, Stave C, Olkin I, Bravata DM (2012) Are organic foods safer or healthier than conventional alternatives? A systematic review. Ann Intern Med 157(5):348-366

Soil Association (2009) Organic Market Report. Bristol, UK.

Sommer S (2001) Effect of composting on nutrient loss and nitrogen availability of cattle deep litter. Eur J Agron 14:123-133

Spaapen JB (2015) A new evaluation culture is inevitable. Organic Farming 1:36-37

Squire G, Gibson GJ (1997) Scaling up and down: matching research with requirements in land management and policy. Scaling up. Cambridge University Press, Cambridge, pp. 17-34

Średnicka-Tober D, Barański M, Seal CJ, Sanderson R, Benbrook C, Steinshamn H, Gromadzka-Ostrowska J, Rembiałkowska E, Skwarło-Sońta K, Eyre M, Cozzi G, Larsen NK, Jordon T, Niggli U, Sakowski T, Calder P, Graham CGC, Sotiraki S, Stefanakis A, Stergiadis S, Yolcu H, Ihatzidimitriou E, Butler G, Stewart G, Leifert C (2016) Higher PUFA and n-3 PUFA, conjugated linoleic acid, $\alpha$-tocopherol and iron, but lower iodine and selenium concentrations in organic milk: a systematic literature review and meta- and redundancy analyses. Br J Nutr. doi:10.1017/S0007114516000349

statista.com (2015) statistica.com/statistik/daten/studie/199421 /umfrage/marktanteil-der-groessten-fuenf-unternehmen-deslebensmitteleinzelhandel/. (Accessed 16 Apr 2016).

Stavi I, Lal R (2013) Agriculture and greenhouse gases, a common tragedy. A review. Agron Sustain Dev 33(2):275-289

Stinner DH (2007) The science of organic farming. Organic farming: an international history. W. Lockeretz. Oxfordshire \& Cambridge, CAB International.

Stolz H, Stolze M, Janssen M, Hamm U (2011) Preferences and determinants for organic, conventional and conventionalplus products - the case of occasional organic consumers. Food Qual Prefer 22(8):772-779

Strassner C, Cavoski I, Di Cagno R, Kahl J, Kesse-Guyot E, Lairon D, Lampkin N, Løes A-K, Matt D, Niggli U, Paoletti F, Pehme S, Rembiakowska E, Schader C, Stolze M (2015) How the organic food system supports sustainable diets and translates these into practice. Frontiers in Nutrition 2:19 
Strotdrees S, Strotdrees L, Braun S, Rahmann G (2011) Ökolandbau 3.0? Landbauforsch SH 354: 5-8, Braunschweig/Trenthorst

Suttie JM, Reynolds SG and Batello C (2005) Grasslands of the world. FAO - plant productin and protection series no. 34, Rome, pp 22

Tauscher B, Brack G, Flachowsky G, Henning M, Köpke U, Meier-Ploeger A, Münzing K, Niggli U, Pabst K, Rahmann G, Willhöft C and Mayer-Miebach E (2003) Bewertung von Lebensmitteln verschiedener Herkunft. Statusbericht 2003. BMEL-Senatsarbeitsgruppe Qualitative Bewertung von Lebensmitteln aus alternativer und konventioneller Produktion. Final Report, Karlsruhe, 161 pp.

Thogersen J (2010) Country differences in sustainable consumption: the case of organic food. Journal of Macromarketing 30(2):171-185

Thornton PK (2010) Livestock production: recent trends, future prospects. Philosophical Transactions of the Royal Society of London B: Biological Sciences 365(1554):2853-2867

Tilman D, Fargione J, Wolff B, D'Antonio C, Dobson A, Howarth R and Swackhamer D (2001) Forecasting agriculturally driven global environmental change. Science, 292(5515), 281-284.

Toenniessen G, Adesina A, de Vries J (2008) Building an allinace for a green revolution in Africa. Annals of New York Academy of Sciences 1136:233-242

Torjusen H, Sangstad L, O'Doherty-Jensen K and Kjaernes U (2004) European consumers' conceptions of organic food: a review of available research, Project Report 4-2004 for National Institute for Consumer Research. Oslo, Norway.

TPorganics (2016) Research and innovation for our future food systems Position paper of TP Organics. (http://tporganics. eu/wpcontent/uploads/2016/06/TPOrganics_position_ paper_future_food_systems_final-1.pdf. $5 \mathrm{pp}$

Tubiello FN, Salvatore M, Rossi S, Ferrara A, Fitton N, Smith P (2013) The FAOSTAT database of greenhouse gas emissions from agriculture. Environ Res Lett 8(1):1-11

Tuck SL, Winqvist C, Mota F, Ahnström J, Turnbull LA, Bengtsson J (2014) Land-use intensity and the effects of organic farming on biodiversity: a hierarchical meta-analysis. J Appl Ecol 51(3):746-755

Tuomisto HL, Hodge ID, Riordan P, Macdonald DW (2012) Does organic farming reduce environmental impacts? - a metaanalysis of European research. J Environ Manag 112:309-320

UN (2012) Secretary-General's Initial Input to the Open Working Group on Sustainable Development Goals. https://sustainabledevelopment.un.org/content/documents/ 1494sgreportsdgs.pdf. New York, (Accessed16 Apr 2016).

UN (2015a) Sustainable Development 2015a. Helping stakeholders shape new global goals for humanity's future. http://www. sustainabledevelopment2015.org (Accessed 16 Apr. 2016).

UN (2015b) World Population Prospects: the 2015 Revision, Key Findings and Advance Tables. Working Paper No. ESA/P/ WP.241.

UNEP (2014) Assessing global land use: balancing consumption with sustainable supply.

UNPD (2015) United Nations, Department of Economic and Social Affairs, Population Division (2015) World Population Prospects: the 2015 Revision, World Population 2015 Wallchart. ST/ESA/SER.A/378. http://esa.un. org/unpd/wpp/Publications/ (Accessed on 16 March 2016).
Vance CP (2001) Symbiotic nitrogen fixation and phosphorus acquisition. Plant nutrition in a world of declining renewable resources. Plant Physiol 127:390-397

Veldstra MD, Alexander CE, Marshall MI (2014) To certify or not to certify? Separating the organic production and certification decisions. Food Policy 49(P2):429-436

Vendomois JS, Cellier D, Velot C, Clair E, Mesnage R, Seralini GE (2010) Debate on GMOs health risks after statistical findings in regulatory tests. Int J Biol Sci 6(6):590-598

Verbeke WSJ, Lahteenmaki L (2009) Consumer appeal of nutrition and health claims in three existing product concepts. Appetite 52:584-692

Vickery BC (1948) Bradford's law of scattering. J Doc 4(3):198-203

Vogt $G$ (2007) The origins of organic farming. Organic farming an international history. W. Lockeretz. Oxfordshire UK and Cambridge MA USA, CABI: 9-29.

Vogt G (2000) Entstehung und Entwicklung des ökologischen Landbaus im deutschsprachigen Raum. Ökologische Konzepte 99, Stiftung Ökologie und Landbau, Bad Dürkheim, 399 pp.

Wägeli S, Hamm U (2015) Consumers' perception and expectations of local organic food supply chains. Organic Agriculture, online first 15(8):1-10

Watson CA, Walker RL, Stockdale EA (2008) Research in organic production systems - past, present and future. J Agric Sci 146(01):1-19

Watson RT, Noble IR, Bolin B, Ravindranath NH, Verardo DJ, Dokken DJ (eds) (2000) Land use, land use change and forestry. Cambridge University Press, Cambridge, UK

WHO (2011) Tackling antibiotic resistance from a food safety perspective in Europe, tackling antibiotic resistance from a food safety perspective in Europe, $88 \mathrm{pp}$.

Willer H, Lernoud J (2016) The World of Organic Agriculture. Statistics and Emerging Trends 2016. FiBL and IFOAM Report. Frick, Bonn, 340pp

Wissenschaftlicher Beirat Agrarpolitik beim BMEL (2015) Wege zu einer gesellschaftlich akzeptierten Nutztierhaltung. Gutachten, Berlin

Wolf B, Haering AM, Hess J (2015) Strategies towards evaluation beyond scientific impact. Pathways not only for agricultural research. Organic Farming 1:3-18

Wood S, Sebastian K, Scherr SJ (2000) Pilot analysis of global ecosystems: agri-ecosystems, international food policy and research. Institute \& World Resources Institute, Washington, DC, USA

Wood SA, Karp DS, DeClerck F, Kremen C, Naeem S, Palm CA (2015) Functional traits in agriculture: agri-biodiversity and ecosystem services. Trends Ecol Evol 30(9):531-539

Zagata L (2012) Consumers' beliefs and behavioral intentions towards organic food. Evidence from the Czech Republic. Appetite 59(1):81-89

Załęcka A, Bügel S, Paoletti F, Kahl J, Bonanno A, Dostalova A, Rahmann G (2014) The influence of organic production on food quality - research findings, gaps and future challenges. J Sci Food Agric 94(13):2600-2604

Zanoli R, Gambelli D, Vairo D (2012) Scenarios of the organic food market in europe. Food Policy 37(1):41-57

Zanoli R, Naspetti S (2002) Consumer motivations in the purchase of organic food: a means-end approach. Br Food J 104:643-653

Zehnder G, Gurr GM, Kühne S, Wade MR, Wratten SD, Wyss E (2007) Arthropod pest management in organic crops. Annu Rev Entomol 52:57-80 